\title{
Effects of altering the ratio of dietary $n-6$ to $n-3$ fatty acids on spontaneous luteolysis in lactating dairy cows
}

\author{
L. F. Greco, ${ }^{*}$ J. T. Neves Neto, ${ }^{*}$ A. Pedrico, ${ }^{*}$ F. S. Lima, ${ }^{*}$ R. S. Bisinotto, ${ }^{*}$ N. Martinez, ${ }^{*}$ E. S. Ribeiro, ${ }^{*}$ \\ W. W. Thatcher, ${ }^{*} \dagger$ C. R. Staples, ${ }^{*}$ and J. E. P. Santos ${ }^{*} \dagger^{1}$ \\ *Department of Animal Sciences, and \\ †DH Barron Reproductive and Perinatal Biology Research Program, University of Florida, Gainesville 32611
}

\begin{abstract}
Objectives were to evaluate the effects of altering the dietary ratio of omega-6 (n-6) to omega-3 (n-3) fatty acids on the profile of fatty acids and expression of genes related to the prostaglandin biosynthesis on endometrial tissue, uterine secretion of $\mathrm{PGF}_{2 \alpha}$, and timing of spontaneous luteolysis in dairy cows. Multiparous lactating Holstein cows $(\mathrm{n}=45)$ were blocked based on milk yield and, within each block, assigned randomly to 1 of 3 dietary treatments at $14 \mathrm{~d}$ postpartum for $90 \mathrm{~d}$. Diets were supplemented with a mixture of Ca salts of fish, safflower, and palm oils to create 3 different ratios of n-6 to n-3 fatty acids, namely R4, R5, and R6, which resulted in $3.9,4.9$, and 5.9 parts of $\mathrm{n}-6$ to 1 part of n-3 fatty acids, respectively. Blood was sampled every $2 \mathrm{~h}$ from d 16 to 23 of the estrous cycle and assayed for concentrations of progesterone and the $\mathrm{PGF}_{2 \alpha}$ metabolite 13,14-dihydro-15-keto- $\mathrm{PGF}_{2 \alpha}$ (PGFM). In a subsequent estrous cycle, endometrial tissue was collected for biopsy on d 8 and endometrial fatty acids profile and gene expression were quantified. The proportion of arachidonic acid of the endometrial fatty acids increased as the dietary ratio n- 6 to n-3 fatty acids increased (R4 $=9.05, \mathrm{R} 5=11.64$, and $\mathrm{R} 6=13.41 \%)$. On the other hand, proportions of eicosapentaenoic $(\mathrm{R} 4=2.85, \mathrm{R} 5$ $=2.14$, and $\mathrm{R} 6=2.02 \%)$ and docosahexaenoic $(\mathrm{R} 4=$ $3.30, \mathrm{R} 5=1.57$, and $\mathrm{R} 6=1.08 \%$ ) decreased as the ratio of $n-6$ to $n-3$ fatty acids in the diet increased. Increasing the ratio of dietary n- 6 to n- 3 fatty acids increased mRNA expression of estrogen receptor 1 , oxytocin receptor, cyclooxygenase 2, prostaglandin E and $\mathrm{F}$ synthases, and steroidogenic acute regulatory protein in endometrium, but decreased expression of peroxisome proliferator-activated receptor gamma and insulin-like growth factor-1. The changes in endometrium gene expression caused by dietary treatments
\end{abstract}

Received May 14, 2018.

Accepted June 29, 2018.

${ }^{1}$ Corresponding author: jepsantos@ufl.edu were associated with changes in the ratio of n- 6 to n- 3 fatty acids in the endometrium. As the ratio increased from R4 to R6, the number of PGFM pulses (R4 = $5.6, \mathrm{R} 5=4.3$, and $\mathrm{R} 6=3.8 \pm 0.6$ pulses; least squares means \pm standard error of the means) decreased, but the amplitude of the greatest PGFM pulse increased $(\mathrm{R} 4=226, \mathrm{R} 5=267$, and $\mathrm{R} 6=369 \pm 38 \mathrm{pg} / \mathrm{mL})$. Luteolysis by d 23 of the estrous cycle was observed in $79.6 \%$ of the cows $(\mathrm{R} 4=11 / 14 ; \mathrm{R} 5=13 / 15$; and $\mathrm{R} 6=11 / 15)$ and day of spontaneous luteolysis did not differ among treatments $(\mathrm{R} 4=20.8 ; \mathrm{R} 5=21.1$; and $\mathrm{R} 6=21.0 \pm 0.4$ ). Three pulses of PGFM was the best predictor of luteolysis in dairy cows. Collectively, supplying the same quantity of fatty acids in the diet of lactating dairy cows, but altering the ratio of n- 6 to n-3 fatty acids, influenced the endometrial fatty acids profile and gene expression and altered the pattern of prostaglandin synthesis; however, the changes were not sufficient to alter the length of the estrous cycle.

Key words: dairy cow, fatty acid, luteolysis, prostaglandin

\section{INTRODUCTION}

Supplemental fat is generally incorporated into dairy cattle diets to increase energy intake while attempting to reduce body fat mobilization and fed during transition period to minimize the incidence of early-lactation disorders (Damgaard et al., 2013). Altering dietary fatty acids intake has been shown to influence various reproductive measures in dairy cattle. Staples et al. (1998) reported that fat supplementation has advantageous effects on reproductive performance of dairy cows, and the benefits of fat feeding go beyond the increase in energy intake. In fact, some of the positive effects seem to be influenced by the type of fatty acids fed (Santos et al., 2008).

High intake of omega-6 (n-6) fatty acids, such as linoleic acid (C18:2 cis-9,cis-12), has the potential to alter the profile of fatty acids of the phospholipids present in cell membranes, resulting in increased proportion 
of arachidonic acid (C20:4 cis-5,cis-8,cis-11,cis-14), which, in turn, might favor the synthesis of series 2 prostaglandin (PG) and eicosanoids (Silvestre et al., 2011), thereby favoring a more proinflammatory state (Calder, 2012). On the other hand, high intake of omega-3 (n-3) fatty acids, especially eicosapentaenoic acid (EPA; C20:5 cis-5,cis-8,cis-11,cis-14,cis-17) and docosahexaenoic acid (DHA; C22:6 cis-5,cis-8,cis11,cis-13,cis-16,cis-19), would increase the proportion of these fatty acids in membrane phospholipids, which are expected to decrease synthesis of series 2 PG and eicosanoids (Mattos et al., 2004), thereby exerting antiinflammatory properties (Calder, 2012). It has been postulated that attenuation of $\mathrm{PGF}_{2 \alpha}$ synthesis by feeding $\mathrm{n}-3$ fatty acids might be one of the mechanisms by which these fatty acids benefit reproduction (Mattos et al., 2000; Santos et al., 2008).

Silvestre et al. (2011) reported improved pregnancy and decreased pregnancy loss for cows fed Ca salts enriched with fish oil during the breeding period compared with cows fed Ca salts of palm oil composed of mostly SFA or MUFA. The fertility benefit from feeding n-3 fatty acids in the breeding period was enhanced when cows were fed $\mathrm{Ca}$ salts rich in $\mathrm{n}-6$ fatty acids during late gestation and early lactation (Silvestre et al., 2011). More recently, Sinedino et al. (2017) showed that incorporating $10 \mathrm{~g}$ of DHA into the diet of dairy cows increased pregnancy per AI and rate of pregnancy. Those authors suggested that increasing dietary n-3 fatty acids may influence embryo development based on changes in interferon-stimulated gene expression when DHA was fed, as fatty acids are important regulators of conceptus development (Ribeiro et al., 2016); however, it also has been speculated that fatty acids might influence luteal lifespan (Mattos et al., 2000; Santos et al., 2008), which could allow less developed conceptuses to develop and establish the needed cross-talk to inhibit the pulsatile uterine secretion of $\mathrm{PGF}_{2 \alpha}$ and luteolysis. In support of this concept, in vitro production of $\mathrm{PGF}_{2 \alpha}$ by bovine endometrial cells was suppressed when the culture media was supplemented with n-3 fatty acids (Mattos et al., 2003). Indeed, when both n-6 and n-3 fatty acids were present in the culture media, increasing the ratio of n-6 to n-3 fatty acids increased the synthesis of $\mathrm{PGF}_{2 \alpha}$ (Caldari-Torres et al., 2006). Similarly, cows on d 15 of the estrous cycle challenged with oxytocin had increased $\mathrm{PGF}_{2 \alpha}$ release when fed diets with increased ratio of n-6 to n-3 fatty acids (Mattos et al., 2002; Petit et al., 2004; Dirandeh et al., 2013). In randomized experiments in humans, consumption of $2.7 \mathrm{~g} / \mathrm{d}$ of n-3 fatty acids extended gestation length (Olsen et al., 1992), presumably by altering the balance of stimulatory and inhibitory PG that influence uterine contractility and parturition. Nevertheless, it is unknown if altering the diet of cattle by supplementing either more n- 6 or more n-3 fatty acids is capable of influencing luteal lifespan that might have implications to fertility.

The hypotheses of the current experiment were that diets containing different ratios of n-6 to n- 3 fatty acids would alter the endometrial fatty acids profile and the expression of genes involved in the luteolytic signaling, thereby affecting the spontaneous pulsatile pattern of $\mathrm{PGF}_{2 \alpha}$ release that could influence luteal lifespan and the length of the estrous cycle. Our objectives were to determine the effects of altering the ratio of $n-6$ to n-3 fatty acids in the diet of Holstein cows on the fatty acids profile and expression of genes related to PG biosynthesis in endometrial tissue and timing of spontaneous luteolysis.

\section{MATERIALS AND METHODS}

The experiment was conducted at University of Florida Dairy Unit (Hague) from December 2011 to July 2012. All procedures for animal handling and care were approved by the University of Florida Animal Care and Use Committee (ARC \# 014-11ANS).

\section{Experimental Design, Cows, Housing, and Feeding}

Details referring to cows, facilities, chemical composition of ingredients, and the respective profiles of fatty acids were described elsewhere (Greco et al., 2015). Briefly, weekly cohorts of cows in their second $(\mathrm{n}=23)$ or greater lactation $(\mathrm{n}=22)$ were blocked by parity $(2$ vs. $>2$ ) and milk yield from d 6 to 10 postpartum and, within each block, randomly assigned to 1 of 3 dietary treatments at $14 \mathrm{~d}$ postpartum ( $\mathrm{n}=15 /$ treatment $)$. The diets were offered as a TMR twice daily at 0730 and $1300 \mathrm{~h}$, and the ratios of n- 6 to n- 3 fatty acids were manipulated by altering the supplemental fat added to the diet. The first ratio was of 3.9 parts of n- 6 to 1 part of n-3 fatty acids in the diet (R4). The second ratio was of 4.9 parts of $n-6$ to 1 part of $n-3$ in the diet (R5). The final ratio was of 5.9 parts of $n-6$ to 1 part of $\mathrm{n}-3$ in the diet (R6). All diets were isocaloric and isonitrogenous, contained the same total concentration of fatty acids, and were formulated to minimize the difference in concentrations of total PUFA (Table 1). Calcium salts enriched in palm oil fatty acids, safflower oil fatty acids, or fish oil fatty acids were used to manipulate the concentration of n- 6 and n- 3 fatty acids in the diets. These Ca salts were blended such that they represented $1.43 \%$ of the diet DM. The amount of supplemental fatty acids was a reasonable quantity 
fed to early-lactation cows to alter tissue fatty acid composition, but also to minimize the risk of milk fat depression. This was particularly important because EPA and DHA, known to be potent disruptors of rumen biohydrogenation of UFA, favor the synthesis of CLA that suppress lipogenesis (Whitlock et al., 2002). The selected amount is similar to that fed to lactating cows by Silvestre et al. (2011) that showed changes in tissue composition of fatty acids and improvements in reproduction because of reduced pregnancy loss.

\section{Estrous Cycle Synchronization to Characterize Spontaneous Luteolysis}

Estrous cycles were synchronized (Figure 1) starting at $40 \pm 3$ DIM with an i.m. injection of $25 \mathrm{mg}$ of $\mathrm{PGF}_{2 \alpha}$ (dinoprost tromethamine; Lutalyse sterile solution, Zoetis, Florham Park, NJ) followed by an i.m. injection of $100 \mu \mathrm{g}$ of GnRH (gonadorelin hydrochloride; Factrel, Zoetis) administered $2 \mathrm{~d}$ later, at 42 DIM. Seven days later, at 49 DIM, cows received a GnRH injection, and

Table 1. Dietary ingredients and nutrient composition of diets

\begin{tabular}{|c|c|c|c|}
\hline \multirow[b]{2}{*}{ Item } & \multicolumn{3}{|c|}{ Treatment $^{1}$} \\
\hline & $\mathrm{R} 4$ & $\mathrm{R} 5$ & $\mathrm{R} 6$ \\
\hline \multicolumn{4}{|l|}{ Ingredient, $\%$ of DM } \\
\hline Corn silage & 18.7 & 18.7 & 18.7 \\
\hline Bermuda silage & 9.0 & 9.0 & 9.0 \\
\hline Alfalfa hay & 6.1 & 6.1 & 6.1 \\
\hline Corn grain, finely ground & 13.8 & 13.8 & 13.8 \\
\hline Citrus pulp & 10.1 & 10.1 & 10.1 \\
\hline Soybean hulls & 20.3 & 20.3 & 20.3 \\
\hline Soybean meal, solvent extract & 10.1 & 10.1 & 10.1 \\
\hline Soybean meal, heat-treated ${ }^{2}$ & 5.7 & 5.7 & 5.7 \\
\hline Molasses & 1.6 & 1.6 & 1.6 \\
\hline Vitamin-mineral-protein premix ${ }^{3}$ & 3.0 & 3.0 & 3.0 \\
\hline Ca salts of palm oil ${ }^{4}$ & 0.73 & 0.65 & 0.53 \\
\hline Ca salts of safflower oil ${ }^{5}$ & 0 & 0.37 & 0.70 \\
\hline Ca salts of fish oil ${ }^{6}$ & 0.70 & 0.41 & 0.20 \\
\hline \multicolumn{4}{|l|}{ Nutrient, DM basis $( \pm \mathrm{SD})$} \\
\hline $\mathrm{NE}_{\mathrm{L}}{ }^{7} \mathrm{Mcal} / \mathrm{kg}$ & 1.62 & 1.62 & 1.62 \\
\hline $\mathrm{CP}, \%$ & $16.6 \pm 0.8$ & $16.6 \pm 0.8$ & $16.5 \pm 0.8$ \\
\hline Starch, \% & 17.3 & 17.3 & 17.3 \\
\hline $\mathrm{NFC}, 8 \%$ & $35.4 \pm 1.9$ & $35.4 \pm 2.0$ & $35.5 \pm 1.9$ \\
\hline $\mathrm{ADF}, \%$ & $16.0 \pm 0.9$ & $15.9 \pm 0.9$ & $15.6 \pm 0.9$ \\
\hline NDF, \% & $38.4 \pm 2.3$ & $38.4 \pm 2.3$ & $38.1 \pm 2.3$ \\
\hline NDF from forage, $\%$ & $17.1 \pm 0.7$ & $17.1 \pm 0.7$ & $17.1 \pm 0.7$ \\
\hline Total fatty acids, $\%$ & $3.66 \pm 0.15$ & $3.82 \pm 0.17$ & $3.88 \pm 0.16$ \\
\hline Total n- 6 fatty acids, $\%$ & $1.260 \pm 0.10$ & $1.447 \pm 0.08$ & $1.587 \pm 0.08$ \\
\hline Total n-3 fatty acids, $\%$ & $0.327 \pm 0.01$ & $0.298 \pm 0.01$ & $0.269 \pm 0.01$ \\
\hline Ratio of n- 6 to n- 3 & 3.9 & 4.9 & 5.9 \\
\hline $\mathrm{Ca}, \%$ & $0.87 \pm 0.07$ & $0.89 \pm 0.07$ & $0.90 \pm 0.08$ \\
\hline $\mathrm{P}, \%$ & $0.33 \pm 0.03$ & $0.33 \pm 0.03$ & $0.33 \pm 0.03$ \\
\hline $\mathrm{Mg}, \%$ & $0.31 \pm 0.02$ & $0.31 \pm 0.02$ & $0.31 \pm 0.02$ \\
\hline $\mathrm{K}, \%$ & $1.48 \pm 0.05$ & $1.48 \pm 0.05$ & $1.48 \pm 0.05$ \\
\hline $\mathrm{Cl}, \%$ & $0.29 \pm 0.03$ & $0.28 \pm 0.03$ & $0.29 \pm 0.03$ \\
\hline $\mathrm{Na}, \%$ & $0.32 \pm 0.01$ & $0.32 \pm 0.01$ & $0.32 \pm 0.01$ \\
\hline
\end{tabular}

${ }^{1}$ Treatments represent the ratio between n- 6 and n- 3 fatty acids in the diet. R4 is a ratio of 3.9 parts of n- 6 to 1 part of $n-3$; R5 is a ratio of 4.9 parts of $n-6$ to 1 part of n-3; R6 is a ratio of 5.9 parts of $n-6$ to 1 part of n-3.

${ }^{2}$ AminoPlus (Ag Processing Inc., Omaha, NE).

${ }^{3}$ Contains (DM basis) 30.0\% ProvAAl LysAAMet (blend of blood meal and protected lysine and methionine, Venture Milling, Salisbury, MD), 28.5\% sodium sesquicarbonate, $13.0 \%$ potassium carbonate, $7.0 \%$ dicalcium phosphate, $7.0 \%$ magnesium oxide, $3.5 \%$ sodium chloride, $1.2 \%$ Availa-4 (Zinpro Co., Eden Prairie, MN), $0.3 \%$ Sel-Plex 2000 (Alltech Biotechnology, Nicholasville, KY), 0.06\% vitamin trace mineral premix, and $0.22 \%$ Rumensin 90 (Elanco Animal Health, Greenfield, IN). Each kg contains $27.8 \%$ CP, $5.2 \%$ Ca, $1.6 \%$ P, $4.1 \%$ $\mathrm{Mg}, 6.8 \% \mathrm{~K}, 10.7 \% \mathrm{Na}, 2.3 \% \mathrm{Cl}, 680 \mathrm{mg}$ of $\mathrm{Zn}, 235 \mathrm{mg}$ of Cu, $422 \mathrm{mg}$ of Mn, $6.6 \mathrm{mg}$ of Se, $23 \mathrm{mg}$ of Co, 13.8 $\mathrm{mg}$ of I, 116,000 IU of vitamin A, 35,000 IU of vitamin D, 1,170 IU of vitamin E, and $450 \mathrm{mg}$ of monensin.

${ }^{4}$ EnerGII, Ca salts of palm oil fatty acids (Virtus Nutrition, Corcoran, CA).

${ }^{5}$ Prequel21, Ca salts enriched in safflower oil fatty acids (Virtus Nutrition).

${ }^{6}$ StrataG113, Ca salts enriched in fish oil fatty acids (Virtus Nutrition).

${ }^{7} \mathrm{NE}_{\mathrm{L}}$ according to NRC (2001) using analyzed feed values and calculated at $24 \mathrm{~kg}$ of DMI/d.

${ }^{8}$ Calculated as $100-(\mathrm{NDF}+\mathrm{CP}+$ fatty acids + ash $)$. 

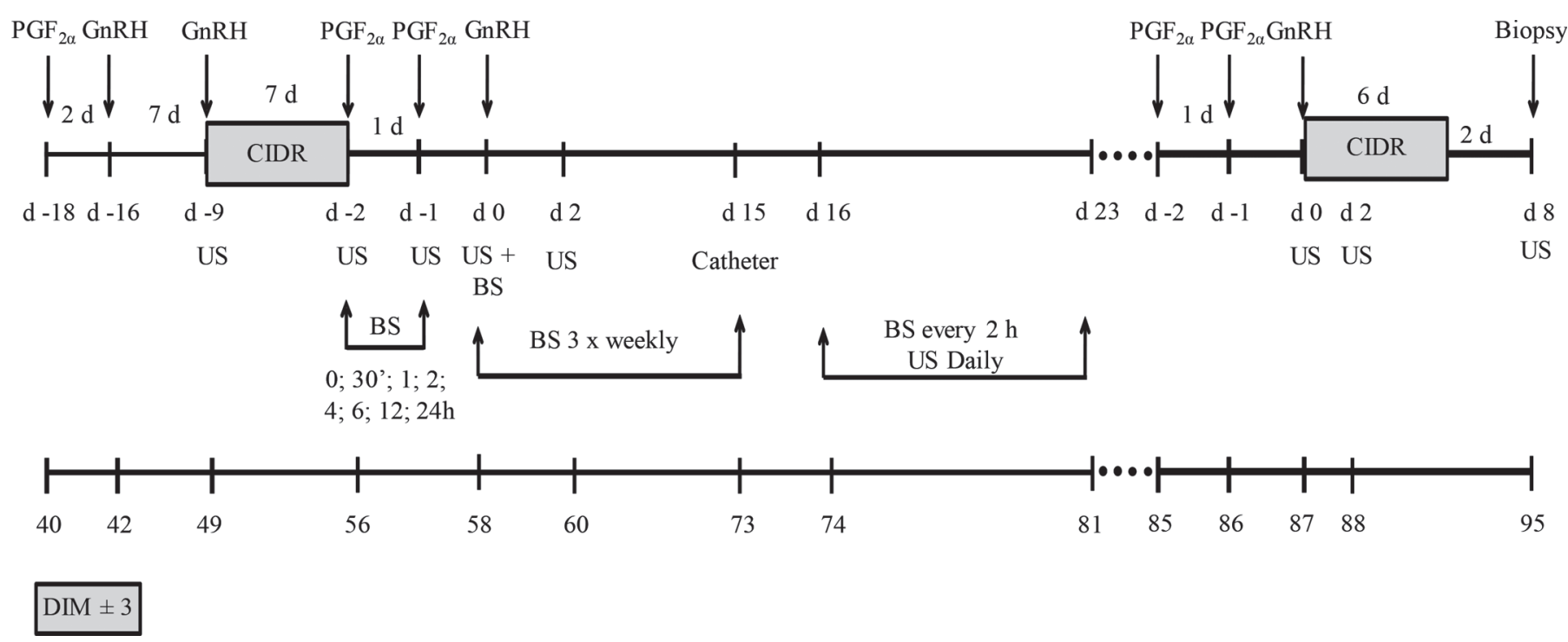

Figure 1. Diagram of estrous cycle synchronization and blood sampling. Biopsy $=$ endometrial tissue collected for biopsy. BS $=$ blood sampling; CIDR $=$ controlled internal drug-release containing $1.38 \mathrm{~g}$ of progesterone; $\mathrm{GnRH}=$ i.m. injection of $100 \mu \mathrm{g}$ of gonadorelin; $\mathrm{PGF} 2 \alpha=\mathrm{i} . \mathrm{m}$. injection of $25 \mathrm{mg}$ of $\mathrm{PGF}_{2 \alpha}$; US = ultrasonography of the ovaries.

then $12 \mathrm{~h}$ after the GnRH a controlled internal drugrelease (CIDR; Eazi-Breed CIDR, Zoetis) insert containing $1.38 \mathrm{~g}$ of progesterone for intravaginal use. The CIDR insert was kept for $6.5 \mathrm{~d}$, until 56 DIM. One hour after the CIDR removal, cows received an i.m. injection of $\mathrm{PGF}_{2 \alpha}$ followed by another injection of $\mathrm{PGF}_{2 \alpha} 24 \mathrm{~h}$ later. A GnRH injection was administered at 58 DIM to induce ovulation and this day was considered $\mathrm{d} 0$ of the estrous cycle, which was confirmed by ultrasonography based on disappearance of a preovulatory follicle within $48 \mathrm{~h}$ of treatment. Cows that did not ovulate to the final $\mathrm{GnRH}$ were re-enrolled in the same protocol for synchronization of the estrous cycle.

\section{Progesterone Clearance After an Injection of $P G F_{2 \alpha}$}

At 56 DIM, $2 \mathrm{~h}$ after the CIDR removal (Figure 1), cows received an injection of $25 \mathrm{mg}$ of $\mathrm{PGF}_{2 \alpha}$ and blood was sampled to evaluate progesterone clearance. A rectangle of approximately $15 \times 5 \mathrm{~cm}$, longitudinal to the mammary vein (i.e., caudal superficial epigastric vein) in both sides of the cow was shaved, cleaned, and disinfected with $70 \%$ alcohol solution. Blood was withdrawn in evacuated tubes containing $\mathrm{K}_{2}$ EDTA (Vacutainer, Becton Dickinson, Franklin Lakes, NJ) at 0, 0.5, 1, 2, 4, 6,12 , and $24 \mathrm{~h}$ relative to $\mathrm{PGF}_{2 \alpha}$ injection, alternating between the sides of the cow between samples. Samples were immediately placed on ice, and within $30 \mathrm{~min}$ plasma was separated by centrifugation at $2,095 \times g$ for $15 \mathrm{~min}$ at $7^{\circ} \mathrm{C}$ and then stored at $-20^{\circ} \mathrm{C}$ for further analyses. Progesterone concentrations were analyzed by RIA using a commercial kit (Coat-a-Count, Siemens Healthcare Diagnostics, Los Angeles, CA). The sensitivity of the assay was $0.05 \mathrm{ng} / \mathrm{mL}$, calculated at 2 standard deviations below the mean counts per minute at maximum biding. Plasma samples containing moderate $(1.6 \mathrm{ng} / \mathrm{mL})$ or high $(7.4 \mathrm{ng} / \mathrm{mL})$ concentrations of progesterone were included throughout all assays and used to calculate the coefficients of variation. The intra-assay coefficients of variation were 5.4 and $4.4 \%$ and the interassay coefficients of variation were 6.6 and $5.3 \%$, respectively, for the moderate and high concentration control samples.

\section{Pharmacologically Induced Luteolysis}

To characterize the pharmacologically induced luteolysis, 2 nonlactating, nonpregnant Holstein cows in mid diestrus bearing a functional corpus luteum (CL) were selected. An indwelling catheter was placed in the jugular vein $3 \mathrm{~h}$ before sampling started. Two blood samples were collected at $30 \mathrm{~min}$ and immediately before cows had been given $25 \mathrm{mg}$ of $\mathrm{PGF}_{2 \alpha}$ i.m. Blood was then sampled at $5,10,15,20,25,30,40,50,60$, $75,90,105,120,150,180,210,240,270,300,330$, and 360 min relative to $\mathrm{PGF}_{2 \alpha}$ injection. Samples continued to be collected at 2-h intervals until $24 \mathrm{~h}$, and then every $6 \mathrm{~h}$ until $48 \mathrm{~h}$ of the $\mathrm{PGF}_{2 \alpha}$ injection. All blood samples collected were immediately placed in ice and plasma was separated by centrifugation $(2,095 \times g$ for 
15 min at $7^{\circ} \mathrm{C}$ ), harvested, and stored at $-20^{\circ} \mathrm{C}$ until analyses. Progesterone concentrations were measured as described above. Concentrations of the $\mathrm{PGF}_{2 \alpha}$ metabolite 13,14-dihydro-15-keto-PGF PG $_{2 \alpha}$ (PGFM) were quantified by an enzyme immune assay as described by Ginther et al. (2010). The intra- and interassay coefficients of variation were 9.1 and $10.6 \%$, respectively.

\section{Spontaneous Luteolysis and Endogenous Release of PGF ${ }_{2 \alpha}$ Based on PGFM}

On d 15 of the estrous cycle, when cows were approximately 73 DIM (Figure 1), an indwelling catheter was placed in the tail vessel following the technique described by Sears et al. (1978). Briefly, the ventral base of the tail was surgically cleaned with soap and disinfected with alcohol. The ventral vertebral groove, where the coccygeal vessels lay, was manually identified and, at approximately $5 \mathrm{~cm}$ from the base of the tail, the vessel was punctured with a thin wall 14 gauge $\times 5$ $\mathrm{cm}$ needle (Monoject, Mansfield, MA). Better access to the vessel was achieved when the angle between the tail and the needle was nearly $60^{\circ}$. Once copious amount of blood started flowing through the needle, approximately $30 \mathrm{~cm}$ of tubing (polyethylene tubing, sterile, PE90, $0.86 \mathrm{~mm}$ ID, $1.70 \mathrm{~mm}$ OD; Becton Dickinson) was inserted in through the vessel, cranially. The needle was then removed from the tail and a blunt cannula (18 gauge $\times 2.5 \mathrm{~cm}$; Monoject) was attached to a PRN 0.1-mL adapter (Becton Dickinson) connected to the extremity of the tubing to seal the tubing. The entire system was flushed with $10 \mathrm{~mL}$ of sterile heparinized saline solution (50 IU/mL, Sigma-Aldrich, Saint Louis, $\mathrm{MO})$. A cotton patch was wrapped around the tail, avoiding contact of the external part of the tubing and the skin of the animal, and the tubing was placed between 2 layers of cotton patch. An extra protection wrap with self-adhesive plastic bandage (Sure Flexx, Stone Mfg. \& Supply co. Inc., Kansa City, MO) was placed to protect from humidity and dirtiness. The bandage was stapled on to the skin to avoid the wrapping falling and misplacing the catheter. To protect against feces and urine, the tail was dressed with a pair of handless sleeves glued to the base of the tail. Finally, a blood sample was taken to verify the catheter was working, and then tubing was rinsed with $15 \mathrm{~mL}$ of the heparinized saline solution.

Serial blood samplings, starting at $0600 \mathrm{~h}$ on d 16 of the estrous cycle, were collected every $2 \mathrm{~h}$ for $7 \mathrm{~d}$ until d 23 of the cycle (Figure 1). Blood was withdrawn using a $12-\mathrm{mL}$ syringe (Monoject), the first $20 \mathrm{~mL}$ of blood and saline was discarded, and $8 \mathrm{~mL}$ of blood was then collected and immediately transferred to an evacuated tube containing $\mathrm{K}_{2}$ EDTA (Vacutainer, Becton Dickinson), mixed by carefully swirling the tube, and placed in ice bath. Samples were centrifuged at 2,095 $\times g$ for 15 min at $7^{\circ} \mathrm{C}$ and plasma was harvested and stored at $-20^{\circ} \mathrm{C}$ for further analyses. Progesterone and PGFM concentrations were measured following the procedures described above.

\section{Estrous Cycle Synchronization for Endometrial Tissue Collection for Biopsy}

On d 5 of a new estrous cycle, when cows were approximately 85 DIM, ovaries were scanned by ultrasonography for detection of a CL and measurements of the largest follicle. Cows with a visible CL received 2 i.m. injections of $\mathrm{PGF}_{2 \alpha} 24 \mathrm{~h}$ apart, followed by a GnRH injection 2 d later (Figure 1). The GnRH injection was considered d 0 of the estrous cycle based on ovulation of a follicle confirmed by ultrasonography. Twelve hours after the GnRH injection, cows received a CIDR insert that was maintained until $d 6$ of the estrous cycle. Progesterone was supplemented through the use of CIDR during metestrus and early diestrus to increase the incorporation of fatty acids in the endometrium, which would resemble late diestrus when luteolysis occurs (Brinsfield and Hawk, 1973; Boshier et al., 1987).

On d 8 of the estrous cycle, endometrial tissue was collected for biopsy from the ipsilateral uterine horn to the CL. Briefly, the cow was restrained in a chute and received an epidural block with $4 \mathrm{~mL}$ of lidocaine hydrochloride $2 \%$ solution (Lidocaine Hydrochloride Injection 2\%, Agrilabs, St. Joseph, MO). The vulvar area was thoroughly cleaned with a $7.5 \%$ povidoneiodine soap scrub (Povidone Iodine Scrub, First Priority Inc., Elgin, IL) and rinsed with alcohol. The vaginal area was inspected and cleansed with gauze pads embedded in diluted chlorhexidine solution $(2 \%$ chlorhexidine gluconate, First Priority) to remove any manure or deposited mucus. The reproductive tract was transrectally palpated to locate the cervix and the uterine horns. A sterilized endometrial forceps (Miltex Hi-Light forceps 30-1485 Eppendorfer, Miltrex, York, PA) was introduced in the closed position through the vagina and cervix and positioned midway through the horn ipsilateral to the CL. The forceps was placed carefully in position to avoid any damage to the uterine wall. The forceps jaw was opened and, with the hand positioned in the rectum of the cow, the endometrium was pressed against the lower jaw and the handle closed to sample the tissue. The forceps was removed through the cervix and vagina and the tissue removed and placed on filter paper and rinsed with sterile PBS 
to remove any blood. The specimen was split in 2 and placed in RNase-free tubes with RNA later solution (Fischer Scientific, Hampton, NH). Tubes were plunged in liquid $\mathrm{N}$, transported to the laboratory, and stored at $-80^{\circ} \mathrm{C}$ for later analyses.

\section{Endometrium Fatty Acid Profile and Gene Expression}

Endometrial tissue was analyzed at the Clinical and Translational Science Institute - Biomedical Mass Spectrometry Core, University of Florida (Gainesville). Briefly, endometrial tissue was homogenized and lipids extracted as previously described (Bligh and Dyer, 1959). The fatty acid cis-10 C17:1 was added as the internal standard. Fatty acid methyl esters were prepared by a modification of the 2-step procedure of Nuernberg et al. (2007) using a combination of sodium methoxide followed by boron trifluoride in methanol. Fatty acid methyl esters were quantified using an Agilent 5973 GC-MS (Agilent, Framingham, TX), equipped with a Trace TR-5MS column $(30 \mathrm{~m} \times 0.25 \mathrm{~mm} \times 0.25 \mu \mathrm{m}$, Thermo Scientific, Rockford, IL). One microliter of sample was injected via the autosampler into the column. The oven temperature was set initially at $150^{\circ} \mathrm{C}$ for $2 \mathrm{~min}$, increased by $5^{\circ} \mathrm{C} / \mathrm{min}$ up to $320^{\circ} \mathrm{C}$, and held for $8 \mathrm{~min}$. The MS was set to full scan, $\mathrm{m} / z 30$ to 600 , at $2.6 \mathrm{scan} / \mathrm{sec}$.

A second specimen of endometrial tissue was used to quantify gene expression. The total RNA was extracted using Trizol reagent (Sigma-Aldrich) with the PureLink RNA Mini Kit (Invitrogen, Carlsbad, CA), according to instructions provided by the manufacturer (https: //assets.thermofisher.com/TFS-Assets/LSG/manuals/ purelink_rna_mini_kit_man.pdf). Following extraction, concentration and purity of isolated RNA were assessed using a NanoDrop 200 spectrophotometer (Thermo Scientific). The DNase (Applied Biosystems, Foster City, CA) treatment was applied for $30 \mathrm{~min}$ at $37^{\circ} \mathrm{C}$ to remove genomic DNA and subsequently heat-denatured at $75^{\circ} \mathrm{C}$ for $15 \mathrm{~min}$. Total RNA (250 ng/reaction) was reverse transcribed to complementary DNA using the high-capacity cDNA Reverse Transcriptase kit (Applied Biosystems) following manufacturer's instructions (https://assets.thermofisher.com/TFS-Assets/LSG/ manuals/cms_042557.pdf). Glyceraldehyde 3-phosphate dehydrogenase (GAPDH) was chosen as the reference gene. The list of genes and primers used are depicted in Supplemental Table S1 (https://doi.org/10 .3168/jds.2018-15065). Genes of interest included those involved in PG metabolism, such as estrogen receptor 1 (ESR1), oxytocin receptor (OXTR), cyclooxygenase 1 (COX1) and 2 (COX2), PGE (PGES) and PGF
(PGFS) synthase, and $\mathrm{PGE}_{2}$ 9-ketoreductase (CBR1); steroid and fatty acid metabolism, steroidogenic acute regulatory protein $(S T A R)$, peroxisome proliferatoractivated receptor $\alpha(P P A R A), P P A R G$, and PPARD; and genes involved in the growth hormone or insulinlike growth factor axis, growth hormone receptor-1A (GHR1A), insulin-like growth factor-1 (IGF1), and insulin-like growth factor binding protein-3 (IGFBP3). Quantitative, reverse transcription-PCR was performed using SYBR Green PCR Master Mix (Applied Biosystems). The cycling conditions applied were activation/ denaturation at $60^{\circ} \mathrm{C}$ for $2 \mathrm{~min}$ and $95^{\circ} \mathrm{C}$ for $10 \mathrm{~min} ; 40$ cycles of 2 steps amplification protocol at $95^{\circ} \mathrm{C}$ for 15 $\mathrm{s}$ and $60^{\circ} \mathrm{C}$ for $1 \mathrm{~min}$; and dissociation at 55 to $95^{\circ} \mathrm{C}$. Primer efficiency ranged from 94 to $103 \%$. Melting curve analysis and agarose gel of PCR products were performed and demonstrated the amplification of a single product of expected size for all genes investigated. Each PCR was performed in triplicate and the abundances of the selected genes were calculated using the cycle threshold $(\mathbf{C t})$ relative to the $\mathrm{Ct}$ of $G A P D H$, which was stable in all treatments. Data are presented using the comparative method developed by Livak and Schmittgen (2001) using treatment R4 as the reference for relative expression of mRNA abundance.

\section{Calculations}

Spontaneous luteolysis was considered when progesterone concentration dropped below $1.0 \mathrm{ng} / \mathrm{mL}$ in sequential blood samples (Mann and Lamming, 2006; Ginther et al., 2007). A pulse of PGFM was defined when concentration in plasma was greater than the mean basal concentration plus 2 standard deviations (Mann and Lamming, 2006). Basal PGFM concentration was calculated as the average of all PGFM values until a pulse was detected. Area under the curve of PGFM pulses was calculated following the formula described by Pruessner et al. (2003).

To characterize spontaneous luteolysis, the events were retrospectively subdivided based on changes in concentrations of progesterone as preluteolytic, luteolytic, and postluteolytic periods according to Ginther et al. (2007). Briefly, the luteolytic period was defined as the period of progressive decrease in progesterone concentration down to $1.0 \mathrm{ng} / \mathrm{mL}$. The preluteolytic period was considered the $24 \mathrm{~h}$ preceding the luteolytic period. The postluteolytic period was considered the 36 $\mathrm{h}$ after progesterone concentrations declined below 1.0 ng/mL (Ginther et al., 2007).

The number of $\mathrm{PGF}_{2 \alpha}$ pulses needed to elicit luteolysis was calculated using the estimates of agreement among the numbers of pulses of PGFM to predict luteal 
regression. The gold standard used was concentration of progesterone below $1.0 \mathrm{ng} / \mathrm{mL}$ in sequential samples. Sensitivity (Se), specificity $(\mathbf{S p})$, positive predictive value (PPV), negative predictive value (NPV), and accuracy were calculated.

The Se was expressed as number of cows correctly detected with luteolysis based on the respective number of pulses of PGFM divided by the number of cows that underwent luteolysis based on progesterone concentration [(number of cows correctly detected with luteolysis using pulses of PGFM/number of all cows with luteolysis $) \times 100$; i.e., truly positive test/(truly positive test + false negative test)]. The Sp was expressed as number of cows correctly identified without luteolysis based on the respective number of pulses of PGFM divided by the number of cows that did not undergo luteolysis based on progesterone concentration [(number of cows correctly detected without luteolysis using pulses of PGFM/number of all cows without luteolysis) $\times 100$; i.e., truly negative test/(truly negative test + false positive test)]. The PPV was calculated as the number of cows correctly identified with luteolysis based on the respective number of pulses of PGFM divided by all cows detected with luteolysis [(number of cows correctly detected with luteolysis based on the respective number of PGFM pulses/number of all cows detected with luteolysis based on the respective number of PGFM pulses $) \times 100$; i.e., truly positive test/(truly positive test + false positive]. The NPV was calculated as the number of cows correctly identified without luteolysis based on the respective number of pulses of PGFM divided by all cows detected without luteolysis [(number of cows correctly detected without luteolysis based on the respective number of PGFM pulses/number of all cows detected without luteolysis based on the respective number of PGFM pulses) $x$ 100; i.e., truly negative test; truly negative + false negative]. Accuracy was calculated as the proportion of correct outcomes [(number of correct tests based on the respective number of PGFM pulses/number of total tests performed) $\times 100]$.

\section{Statistical Analysis}

Data were analyzed using the GLIMMIX procedure of SAS (SAS ver. 9.4, SAS Inst. Inc., Cary, NC) fitting either a Gaussian or Poisson distribution according to the type of data. Tests for normality of residuals and homogeneity of variances were conducted for each dependent variable subjected to ANOVA after model fit. Transformation was applied when needed before statistical analyses to normalize the residuals or stabilize the variance. Data with repeated measurements over time within the same experimental unit were analyzed with cow nested within treatment as a random effect for testing the effects of treatment. All models included the fixed effects of treatment, parity ( 2 or $>2$ ), time, and interactions between treatment and time, treatment and parity, and treatment and parity and time. The time reference for the models was hour or day relative to an event. Polynomial orthogonal contrasts were performed to determine linear or quadratic effects of altering the ratios of n- 6 to n- 3 fatty acids in the diet. The covariance structure (compound symmetry, heterogeneous compound symmetry, autoregressive 1, heterogeneous autoregressive 1 , Toeplitz) that resulted in the lowest correct Akaike's information criterion was selected as best fit for each model. For unequally spaced measurements, the spatial power covariance structure was used. When a single measurement was determined for each cow, the model included the effects of treatment and parity.

Data from quantitative PCR were analyzed with a mixed model using the results of delta Ct. The statistical models included the fixed effect of treatment and the random effects of block and plate used in the PCR assays. The delta-delta $\mathrm{Ct}$ were obtained from delta $\mathrm{Ct}$ least squares means differences of pairwise comparisons among treatments and the reference treatment R4 (Yuan et al., 2006). The relative expression of each gene for each treatment was obtained by raising the PCR amplification efficiency $(\mathrm{E}=2)$ to the power of deltadelta Ct (Yuan et al., 2006) to express the fold change relative to the reference treatment. Confidence limits were computed for graphical representation of relative expression from the lower and upper confidence interval after adjustment by the method of Tukey obtained for delta Ct least squares means differences described by Yuan et al. (2006). Additional analyses of gene expression were performed using endometrial fatty acids as the explanatory variable. The fatty acids in the endometrial were categorized into 3 percentiles based on the observed proportion of n- 6 to n- 3 fatty acids as low $($ mean $=4.45$, range $=2.65$ to 5.6$)$, medium $($ mean $=$ 8.81 , range $=8.12$ to 9.91$)$, or high $($ mean $=11.10$, range $=10.06$ to 14.27 ) ratio.

The agreement between the number of $\mathrm{PGF}_{2 \alpha}$ pulses needed to elicit CL regression with the proportion of cows undergoing or not luteolysis was calculated by kappa statistic in PROC FREQ of SAS. The kappa value and the respective $95 \%$ confidence intervals are depicted. Statistical significance was declared when $P$ $\leq 0.05$ and tendency to differ when $0.05<P \leq 0.10$. Results are presented as least squares means \pm standard error of the means. 


\section{RESULTS}

Detailed descriptions of DMI and lactation performance are presented elsewhere (Greco et al., 2015). The intake of fatty acids did not differ among treatments and averaged $953 \pm 24 \mathrm{~g} / \mathrm{d}$. Increasing the ratio of $\mathrm{n}-6$ to $\mathrm{n}-3$ fatty acids in the diet increased $(P<0.001)$ the intake of linoleic acid $(\mathrm{R} 4=298.1, \mathrm{R} 5=329.5$, and $\mathrm{R} 6$ $=369.4 \mathrm{~g} / \mathrm{d})$, but decreased $(P<0.001)$ that of EPA and DHA combined $(\mathrm{R} 4=21.3, \mathrm{R} 5=14.9$, and $\mathrm{R} 6=$ $10.0 \mathrm{~g} / \mathrm{d})$.

\section{Concentrations of PGFM after PGF $_{2 \alpha}$ Injection}

Administration of $25 \mathrm{mg}$ of $\mathrm{PGF}_{2 \alpha}$ generated an enormous pulse of PGFM in plasma detected within 5 min after the injection (Figure 2). Concentrations of PGFM reached almost $4,000 \mathrm{pg} / \mathrm{mL}$ in cow 7432 and over 6,000 $\mathrm{pg} / \mathrm{mL}$ in cow 15891. Both cows experienced CL regression and concentrations of progesterone dropped below $1.0 \mathrm{ng} / \mathrm{mL}$ within $24 \mathrm{~h}$ and remained below $0.5 \mathrm{ng} /$ $\mathrm{mL}$ at $48 \mathrm{~h}$ of $\mathrm{PGF}_{2 \alpha}$ injection, when blood sampling stopped. No additional PGFM pulse was detected in cow 7432, whereas a second pulse was observed at 105 min of $\mathrm{PGF}_{2 \alpha}$ injection in cow 15891.

\section{Progesterone Clearance After PGF $_{2 \alpha}$ Injection}

After administration of $\mathrm{PGF}_{2 \alpha}$, the concentrations of progesterone in plasma decayed for the first $1 \mathrm{~h}$, from 5.6 to $3.2 \mathrm{ng} / \mathrm{mL}$, after which it increased to $4.2 \mathrm{ng} / \mathrm{mL}$ at $2 \mathrm{~h}$ and then declined to basal concentrations below $1.0 \mathrm{ng} / \mathrm{mL}$ by $24 \mathrm{~h}$ of $\mathrm{PGF}_{2 \alpha}$ injection (Figure 3 ). The pattern of progesterone decline after administration of $\mathrm{PGF}_{2 \alpha}$ did not differ with treatment.

\section{Luteolysis and Endogenous Release of PGFM}

One cow from R4 treatment was excluded from the statistical analyses because the estrous cycle was not synchronized. The remaining 44 cows had the estrous cycle synchronized and were included in all analyses. During late diestrus, progesterone concentrations presented a pulsatile pattern that was observed in cows that underwent luteolysis as well as in cows that maintained the CL up to d 23 of the estrous cycle. A representative

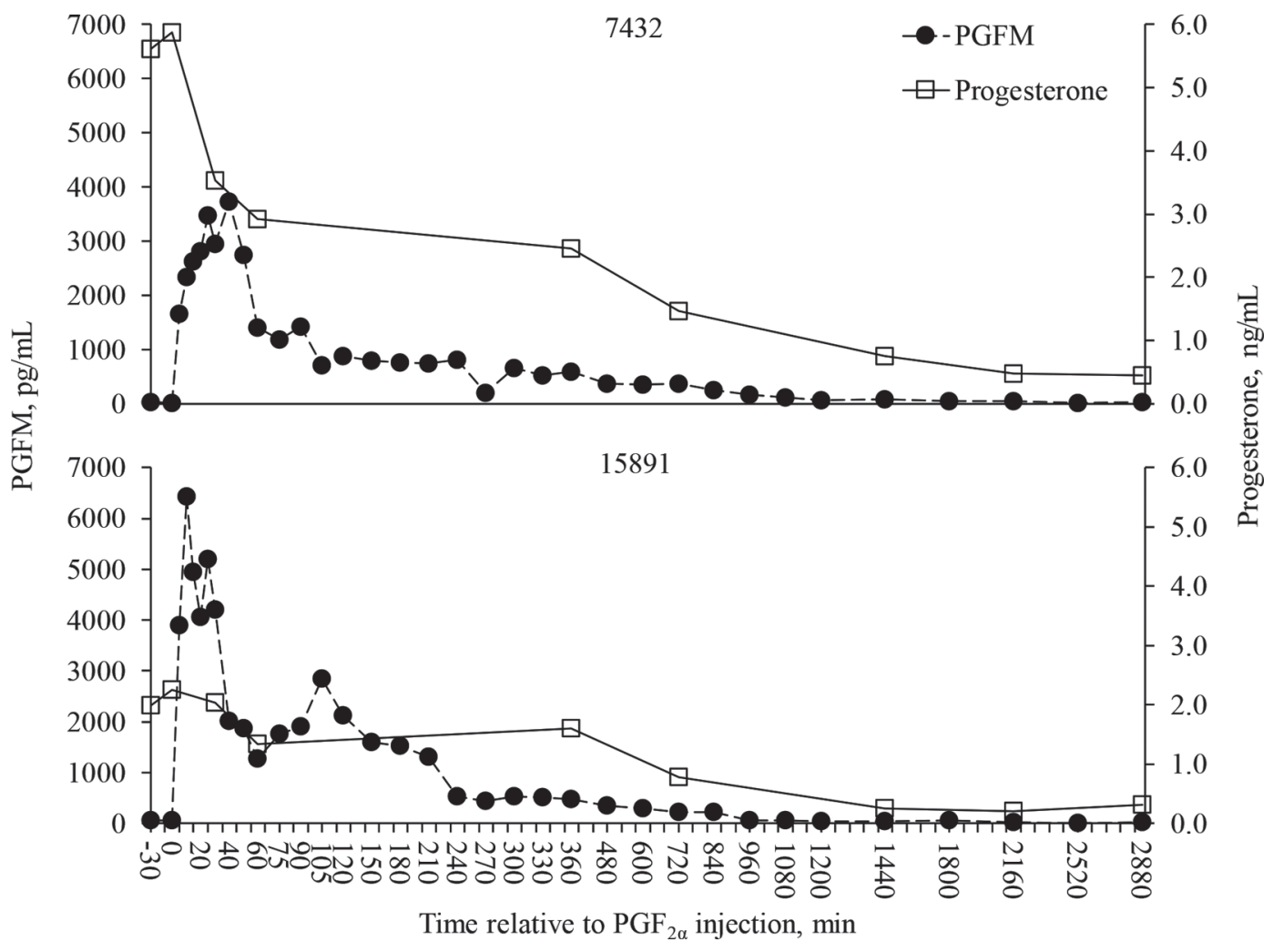

Figure 2. Concentrations of progesterone and 13,14,dihydro-15-keto-PGF ${ }_{2 \alpha}$ metabolite (PGFM) in plasma of nonlactating, nonpregnant Holstein cows (cows 7432 and 15891) bearing a functional corpus luteum, before and after an i.m. injection of 25 mg of dinoprost as tromethamine salt. 


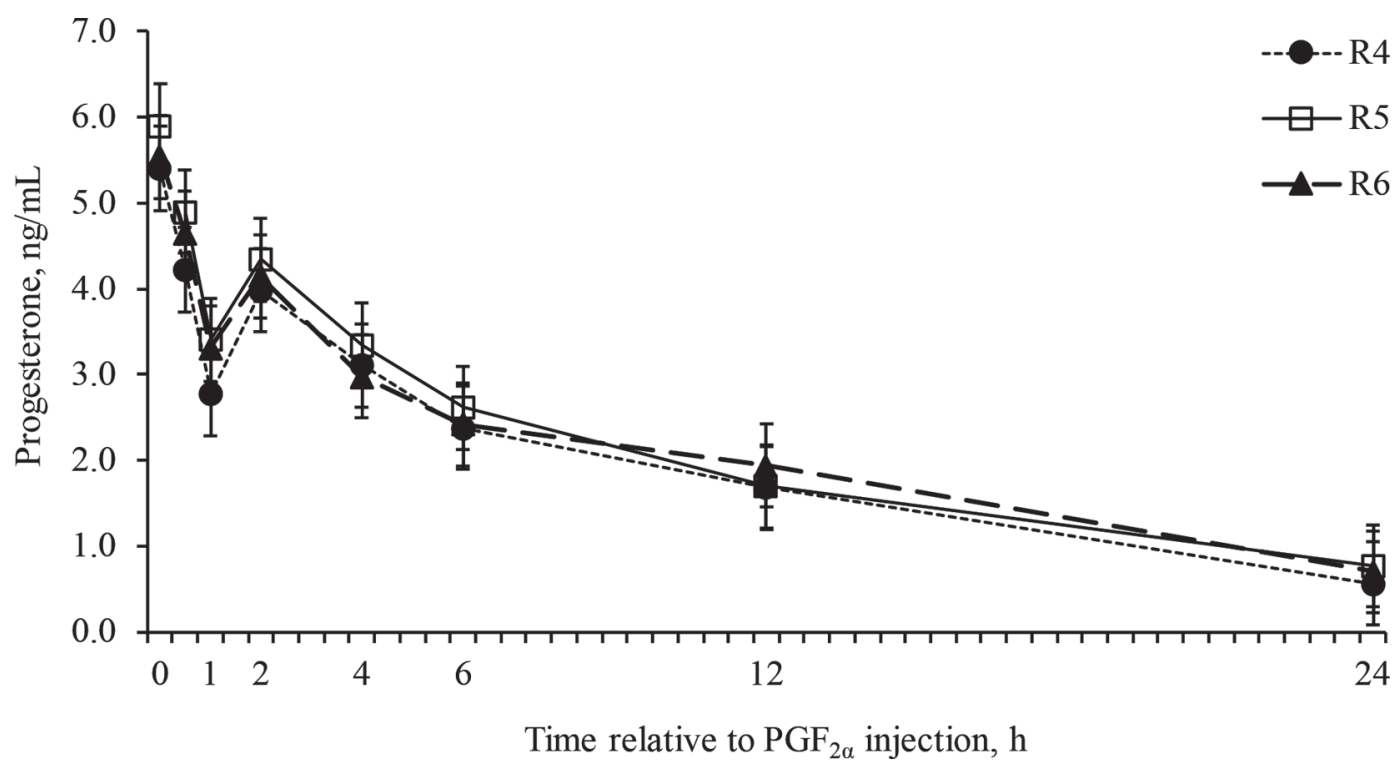

Figure 3. Progesterone concentrations in plasma of lactating Holstein cows fed a ratio of 3.9 to 1 (R4; $\mathrm{n}=15$ cows), 4.9 to 1 (R5; $\mathrm{n}=15$ cows), and 5.9 to 1 (R6; $\mathrm{n}=15$ cows) $\mathrm{n}-6$ to $\mathrm{n}-3$ fatty acids in the diet, after an i.m. injection of $25 \mathrm{mg}$ of $\mathrm{PGF} \mathrm{F}_{2 \alpha}$. Effect of treatment $(P=0.83)$, time $(P<0.001)$, and interaction between treatment and time $(P=0.99)$. Linear $(P=0.72)$ and quadratic $(P=0.61)$ effects of increasing the ratio of n- 6 to $\mathrm{n}-3$ fatty acids in the diet. Mean progesterone concentrations during the sampling period were $2.80 \pm 0.41,3.15 \pm 0.40$, and 3.01 $\pm 0.39 \mathrm{ng} / \mathrm{mL}$, respectively, for cows receiving the R4, R5, and R6 diets. Error bars represent SEM.

cow that underwent luteolysis and one that maintained the CL is depicted in Figure 4. In general, cows that underwent luteolysis had 2 pulses of PGFM during the preluteolytic period, 2 pulses during the luteolytic period, and 1 pulse during the postluteolytic period.

The proportions of cows undergoing luteolysis by d 20 or 23 of the estrous cycle did not differ among treatments (Table 2). For cows undergoing luteolysis, the basal concentration of PGFM was similar among treatments and averaged $30.7 \pm 3.8 \mathrm{pg} / \mathrm{mL}$ (Table 2). The total number of pulses of PGFM decreased $(P<$ 0.01 ) with an increasing ratio of n-6 to n-3 fatty acids. Number of preluteolytic and luteolytic pulses tended $(P$ $<0.10)$ to decrease with an increasing ratio from R4 to R6. The area under the curve of the PGFM pulses within the preluteolytic, luteolytic, or postluteolytic periods did not differ among treatments (Table 2). However, increasing the ratio from $\mathrm{R} 4$ to $\mathrm{R} 6$ increased $(P=0.05)$ the area under the curve of the greatest pulse of PGFM. During the preluteolytic period, the greatest PGFM pulse was greater for cows fed R4 than those fed R5 or R6 $(P<0.05$; Figure 5A). The second greatest pulse of the preluteolytic period did not differ among treatments. The luteolytic period was characterized by at least 2 major PGFM pulses in most cows, and the greatest pulse was greater $(P<0.05)$ for R6 than R5 or R4 (Figure 5B). The second greatest pulse of the luteolytic period had smaller amplitude and only minor differences were observed. During the postluteo- lytic period, cows had, on average, 1 pulse of PGFM and the amplitude of the pulse was greater $(P<0.05)$ for cows fed R6 than those fed R4 or R5 (Figure 5C).

One cow underwent luteolysis with 2 PGFM pulses, however, the measures of reliability indicated that a minimum of 3 pulses of $\mathrm{PGF}_{2 \alpha}$ were required to induce CL regression with the highest accuracy and with the best kappa value (Table 3 ). For the 8 cows that did not undergo luteolysis by d 23, the basal PGFM averaged $36.0 \pm 6.5 \mathrm{pg} / \mathrm{mL}$ and the number of pulses and the area under the curve for those pulses did not differ among treatments (Table 2).

All cows, with no exception, had progesterone profiles with a pulsatile pattern as exemplified for cows in Figure 4 , but the average concentrations of progesterone showed an elevation immediately before the beginning of the luteolytic period that was followed by a sharp decline to below $1.0 \mathrm{ng} / \mathrm{mL}$ in the next $36 \mathrm{~h}$ (Figure 6). Concentrations of progesterone did not differ among treatments during the preluteolytic period and averaged $6.16 \pm 0.43,5.41 \pm 0.40$, and $6.14 \pm 0.42 \mathrm{ng} / \mathrm{mL}$ in the $24 \mathrm{~h}$ preceding the luteolytic period in cows fed R4, R5, and R6, respectively. During the luteolytic period, concentrations of progesterone were greater $(P<0.05)$ for cows fed R4 than R5 or R6, particularly between 8 and $24 \mathrm{~h}$ after onset of luteolysis, which averaged 3.74 $\pm 0.33,2.93 \pm 0.31$, and $2.90 \pm 0.32$, respectively. During the postluteolytic period, concentrations remained below $1.0 \mathrm{ng} / \mathrm{mL}$ in all 36 cows that underwent lute- 
olysis. Of the cows that underwent luteolysis, $1 \mathrm{R} 4,1$ R5, and 4 R6 had progesterone concentrations during the postluteolytic phase that did not drop below 0.3 $\mathrm{ng} / \mathrm{mL}$. The remaining 30 cows with regressed CL had progesterone concentrations that remained below 0.3 $\mathrm{ng} / \mathrm{mL}$ during the postluteolytic period.

\section{Endometrium Fatty Acid Profile and Gene Expression}

Altering the ratio of $n-6$ to n- 3 fatty acids in the diet resulted in changes in the profile of fatty acids of the endometrium of lactating dairy cows (Table 4). The concentrations of palmitic acid (C16:0), stearic acid (C18:0), oleic acid (C18:1), eicosadienoic acid (C20:2 cis-11,cis-14), and dihomo-gamma-linolenic acid (C20:3 cis-8, cis-11,cis-14) did not differ among treatments. The proportion of heptadecanoic acid (C17:0) was greater $(P=0.02)$ in the endometrium of cows fed R4 than R5 or R6. Although cows fed R6 consumed an additional $71 \mathrm{~g}$ of linoleic acid daily compared with cows fed R4, the proportion of linoleic acid was not altered by treatments and averaged $13.5 \%$ of the total endometrial fatty acids. However, the concentration of arachidonic acid, a product of desaturation and elongation of linoleic acid, in the endometrial tissue increased $(P<0.01)$ as the ratio of dietary n- 6 to $n-3$ fatty acids increased. On the other hand, the concentrations of EPA and DHA decreased linearly $(P<0.01)$ as the ratio of dietary n- 6 to n-3 fatty acids increased. The proportions of total n- 6 and n-3 fatty acids in the endometrium were affected $(P<0.01)$ by dietary treatments, and they followed opposite directions as the ratio of dietary n- 6 to n- 3 fatty acids increased. Because of such changes in fatty acids composition of endometrial lipids, the ratio of $n-6$ to n-3 fatty acids in the endometrium increased $(P<$ 0.01 ) from 4.53 to 9.85 as the dietary ratio increased from R4 to R6.

Cow 7389

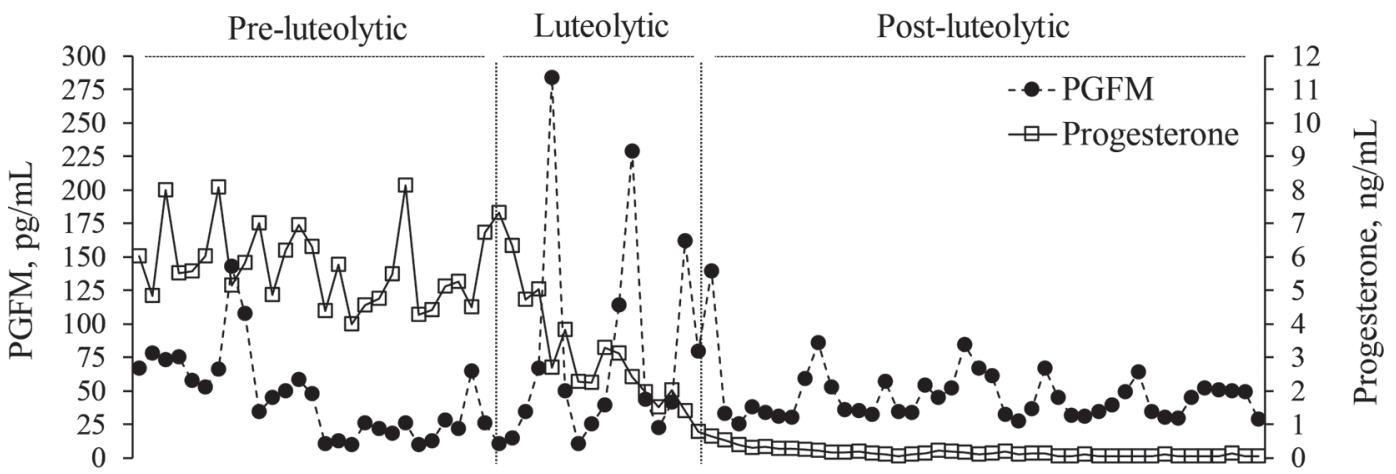

Cow 7381

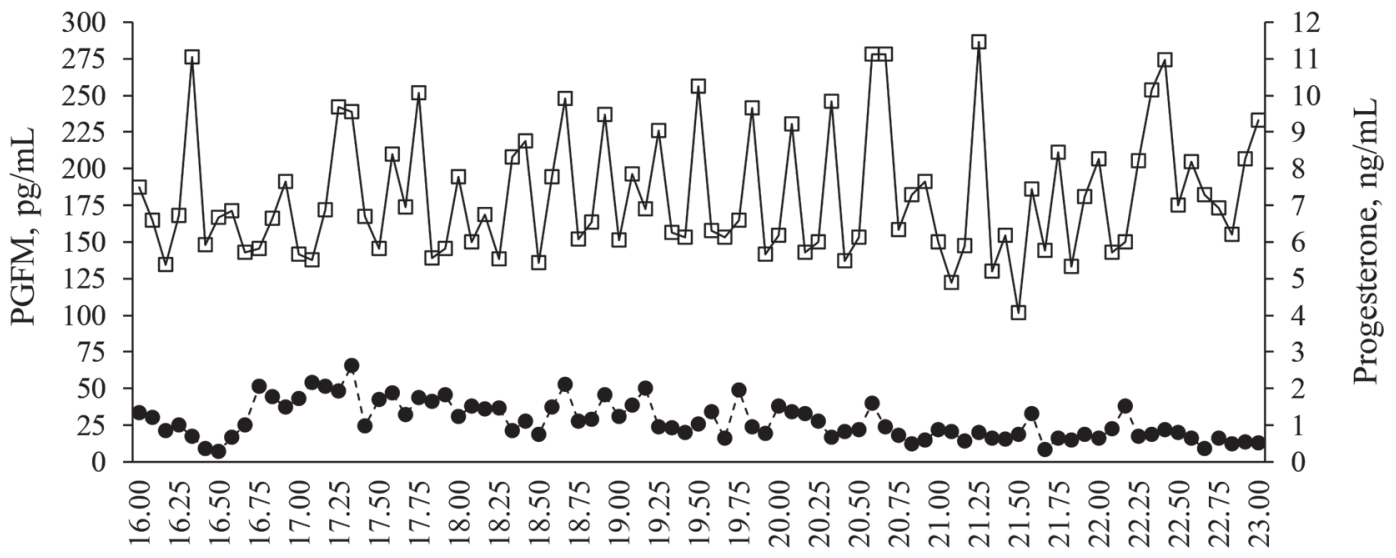

Day of the estrous cycle

Figure 4. Progesterone and 13,14,dihydro-15-keto-PGF ${ }_{2 \alpha}$ metabolite (PGFM) in plasma from d 16 to 23 of the estrous cycle of a representative cow that underwent luteolysis (no. 7389) and a cow that maintained the corpus luteum by d 23 (no. 7381). 
Table 2. Effect of altering the ratio of dietary n-6 to n-3 fatty acids on timing of luteolysis and $\mathrm{PGF}_{2 \alpha}$ metabolite 13,14 -dihydro-15-keto-PGF $2 \alpha$ (PGFM) concentrations and pulses of lactating Holstein cows

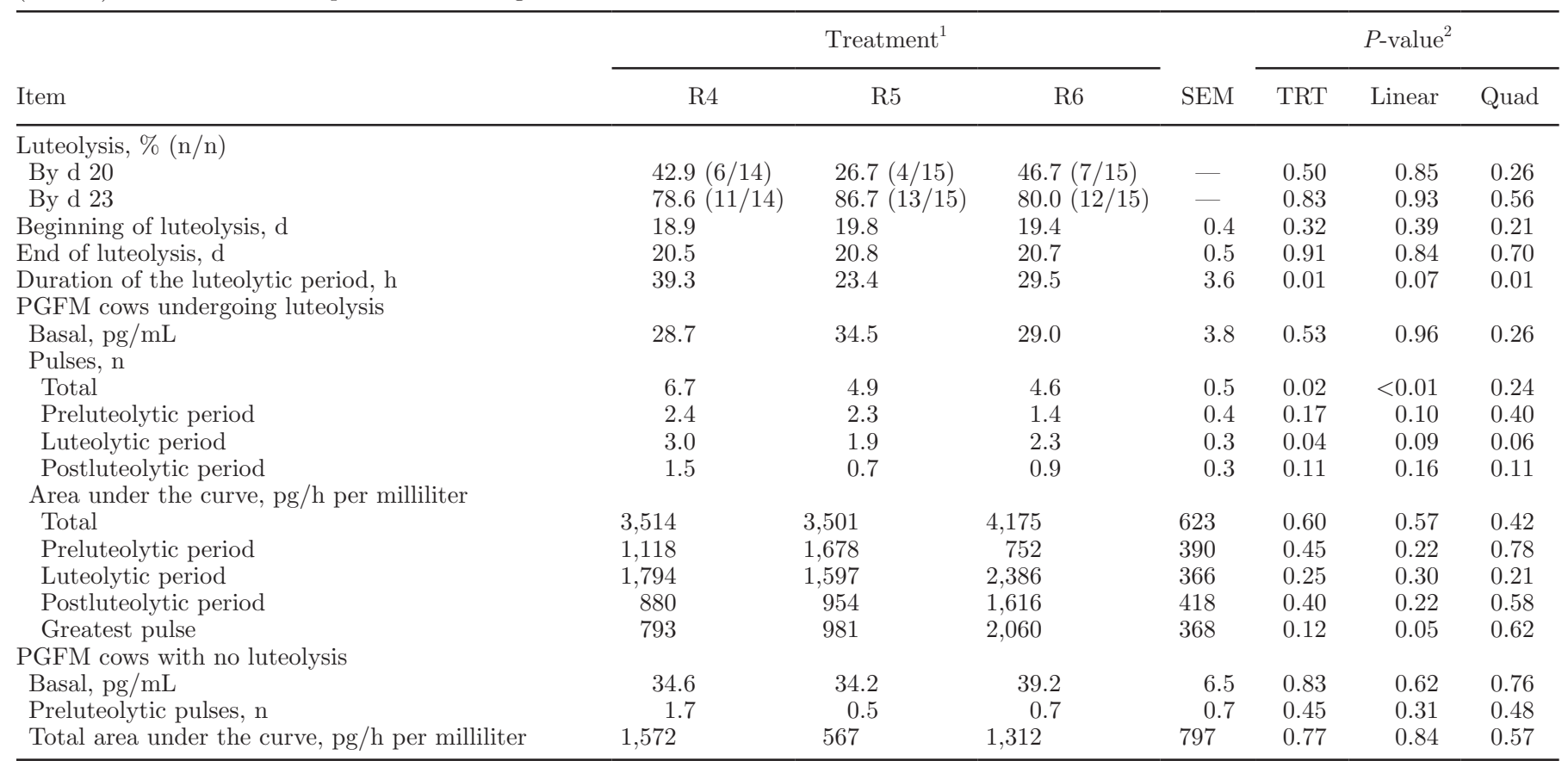

${ }^{1} \mathrm{R} 4=$ ratio of 4 to 1 of n- 6 to n- 3 fatty acids; R5 = ratio of 5 to 1 of n- 6 to n- 3 fatty acids; R 6 = ratio of 6 to 1 of n- 6 to n- 3 fatty acids.

${ }^{2} \mathrm{TRT}=$ effect of treatment; Linear = linear effect of altering the ratio of n- 6 to n- 3 fatty acids; Quad = quadratic effect of altering the ratio of n-6 to n-3 fatty acids.

Altering the ratio of $n-6$ to $n-3$ fatty acids on the diet of lactating dairy cows influenced the expression of genes associated with the luteolytic cascade, fatty acid metabolism, and growth hormone/IGF axis in the endometrium (Figure 7). Increasing the dietary ratio of n-6 to n-3 fatty acids resulted in a linear increase in the mRNA abundance of ESR1 $(P<0.001)$, OXTR $(P=$ $0.01)$, COX2 $(P<0.001), P G E S(P=0.04), P G F S(P$ $=0.02), \operatorname{STAR}(P<0.001)$, and IGFBP3 $(P=0.03)$; however, the same increase in the dietary ratio of $n-6$ to n-3 fatty acids resulted in a linear decrease in the mRNA abundance of PPARG $(P<0.001)$ and $I G F 1$ $(P=0.10)$. Treatment did not influence endometrial expression of PLC, COX1, CBR1, PPARA, PPARD, and GHR1A in dairy cows (Figure 7).

Linear positive relationships were observed between the expression of selected genes and the ratio of n- 6 to n-3 fatty acids analyzed in the endometrium of dairy cows (Figure 8). Scatter plots depicting the delta $\mathrm{Ct}$ relative to endometrial fatty acids showed that the mRNA expressions of ESR1, OXTR, COX2, PGES, and $P G F S$ increased $(P<0.01)$ with increased ratio of endometrial n-6 to n-3 fatty acids. On the other hand, the opposite response was observed for PPARG expression. As the ratio of n- 6 to n- 3 fatty acids decreased, expression of PPARG increased. Indeed, after grouping cows according to the fatty acid composition of the endometrium as low (mean $=4.45$, range $=2.65$ to 5.6 ), medium $($ mean $=8.81$, range $=8.12$ to 9.91$)$, or high $($ mean $=11.10$, range $=10.06$ to 14.27$)$ ratio of $n-6$ to n-3 fatty acids, we observed that the relative expression of ESR1 $(P<0.001)$, OXTR $(P=0.08), C O X 2(P=$ $0.04), \operatorname{PGES}(P=0.02)$, and PGFS $(P=0.06)$ in the endometrium increased as the ratio n-6 to n-3 fatty acids increased (Figure 9). Conversely, expression of PPARG increased $(P<0.001)$ as the ratio of $\mathrm{n}-6$ to $\mathrm{n}-3$ fatty acids in the endometrium decreased (Figure 9).

\section{DISCUSSION}

Prostaglandins are local mediators produced by many tissues, particularly the uterus, that play critical roles in female reproduction. One of the key roles of $\mathrm{PG}$ is the control of luteal lifespan; in particular, $\mathrm{PGF}_{2 \alpha}$ is known to be the molecule responsible for luteolysis in ruminants (McCracken et al., 1972). The precursor of uterine $\mathrm{PGF}_{2 \alpha}$ is arachidonic acid, which is present in the endometrial phospholipids and is formed from elongation and desaturation of linoleic acid (Leonard et al., 2004). After exposure to progesterone during diestrus, the endometrium accumulates arachidonic acid (Brinsfield and Hawk, 1973), which serves as precur- 


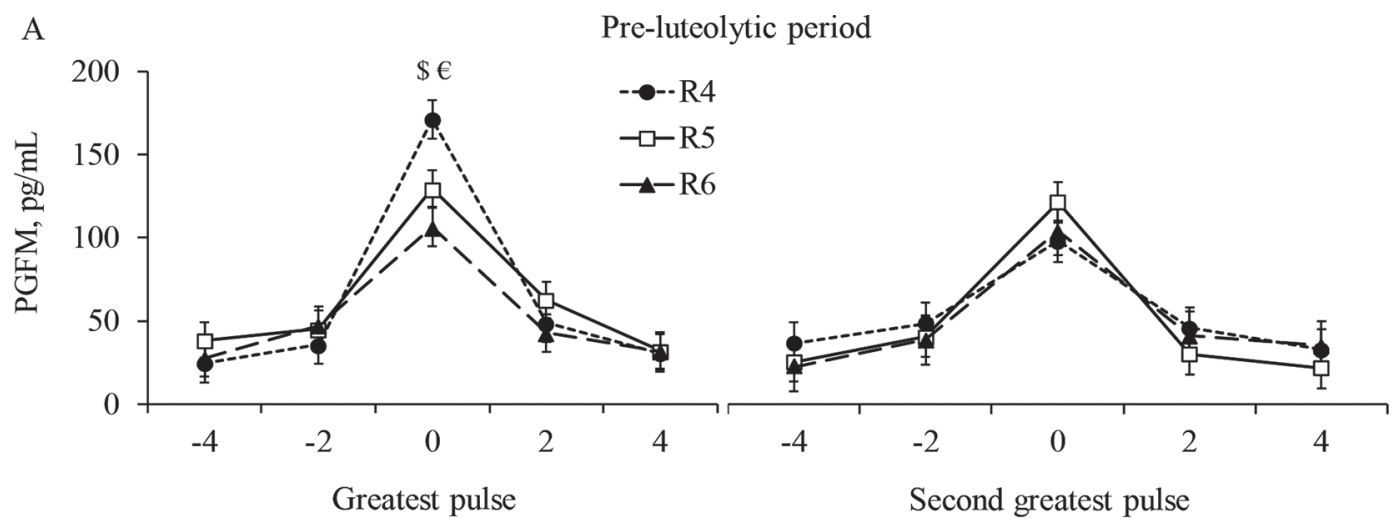

Hour relative to the peak of PGFM pulse
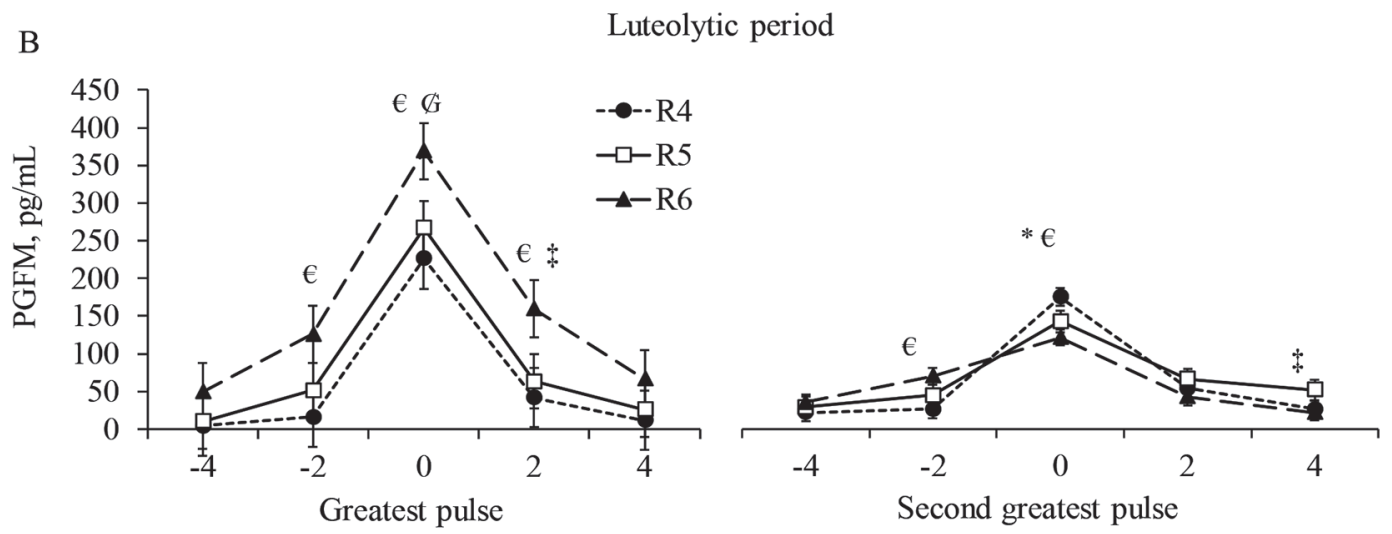

Hour relative to the peak of PGFM pulse

$\mathrm{C}$

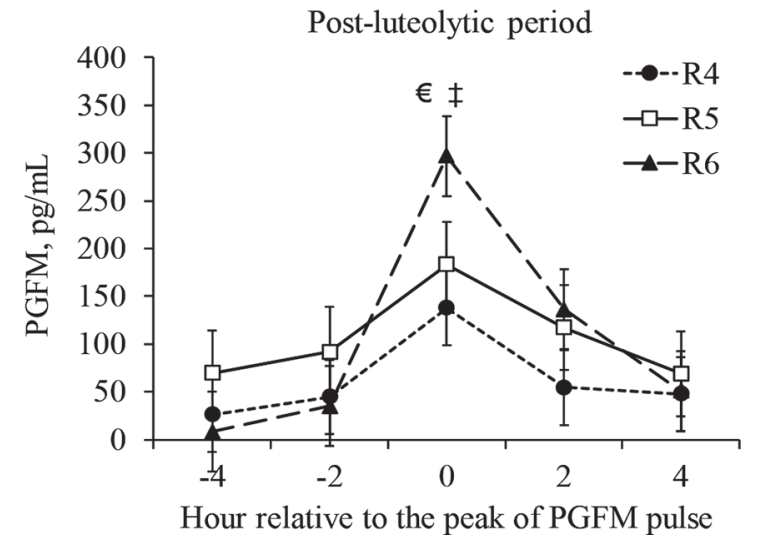

Figure 5. Concentrations of 13,14,dihydro-15-keto- $\mathrm{PGF}_{2 \alpha}$ metabolite (PGFM) in plasma of lactating Holstein cows that underwent luteolysis and were fed a ratio of 3.9 to 1 (R4; $\mathrm{n}=11$ cows), 4.9 to 1 (R5; $\mathrm{n}=13$ cows), and 5.9 to 1 (R6; $\mathrm{n}=12$ cows) n- 6 to n-3 fatty acids in the diet during the preluteolytic (A), luteolytic (B), and postluteolytic (C) periods. Within an hour, pairwise differences $(P<0.05)$ are represented as $\$$ $=\mathrm{R} 4$ vs. $\mathrm{R} 5, €=\mathrm{R} 4$ vs. R6, or $\mathrm{G}=\mathrm{R} 5$ vs. R6; tendencies $(P<0.10)$ are represented as $*=\mathrm{R} 4$ vs. R5, or $\ddagger=\mathrm{R} 5$ vs. R6. Error bars represent SEM.

sors of either $\mathrm{PGF}_{2 \alpha}$ or $\mathrm{PGE}_{2}$. Experiments in vitro have shown that production of $\mathrm{PGF}_{2 \alpha}$ by bovine endometrial cells was suppressed when the culture media was supplemented with n-3 fatty acids (Mattos et al., 2003). In fact, when both n- 6 and n-3 fatty acids were present in the culture media, increasing the ratio of n-6 to n-3 fatty acids resulted in increased synthesis of $\mathrm{PGF}_{2 \alpha}$ (Caldari-Torres et al., 2006). Furthermore, in vivo experiments showed that diets with increased n-3 fatty acids suppressed the release of $\mathrm{PGF}_{2 \alpha}$ after 
Table 3. Measures of reliability of number of 13,14-dihydro-15-keto-PGF $2 \alpha$ (PGFM) pulses to elicit luteal regression

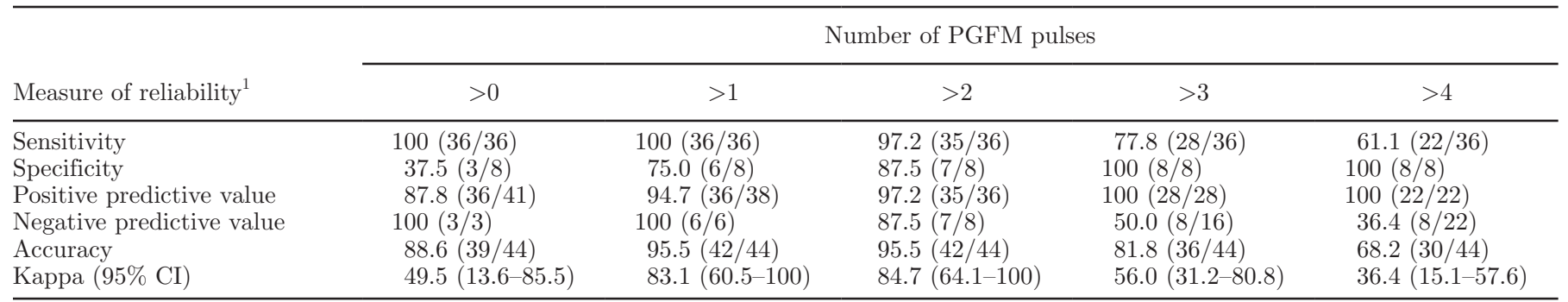

${ }^{1}$ Sensitivity $=$ (number of cows correctly detected with luteolysis based on the respective number of PGFM pulses/number of all cows with luteolysis $) \times 100$; specificity $=$ (number of cows correctly detected without luteolysis based on the respective number of PGFM pulses/number of all cows without luteolysis $) \times 100$; positive predictive value $=($ number of cows correctly detected with luteolysis based on the respective number of PGFM pulses/number of all cows detected with luteolysis) $\times 100$; negative predictive value $=$ (number of cows correctly detected without luteolysis based on the respective number of PGFM pulses/ number of all cows detected without luteolysis $) \times 100$; accuracy $=($ number of correct tests based on the respective number of PGFM pulses/number of total tests performed) $\times 100$.

an oxytocin challenge (Mattos et al., 2002; Petit et al., 2004; Dirandeh et al., 2013). These and numerous other experiments led to the concept that altering the fatty acid profile of the diet might influence endometrial PG release, and feeding more n-3 fatty acids might attenuate the luteolytic signals and favor the maintenance of the CL and favor pregnancy in farm animals (Abayasekara and Wathes, 1999). Nevertheless, the PG response in cows fed diets supplemented with n-3 fatty acids following a challenge with oxytocin has not been consistent (Gulliver et al., 2012). Perhaps, lack of consistent attenuation in PG release after stimulation with oxytocin might be related to the amount of n-3 fatty acids reaching the duodenum for absorption and subsequent incorporation into reproductive tissues.
Although we noted an increase in n-3 fatty acids in the endometrium of cows fed R4, the length of the luteal phase and the day of CL regression was not altered in the current experiment. Similar to our findings, day of luteal regression was not altered in lactating dairy cows fed diets supplemented with fat sources differing in fatty acid profile (Hutchinson et al., 2012).

Silvestre et al. (2011) reported improved pregnancy per AI and reduced pregnancy loss for cows fed Ca salts enriched in EPA and DHA during the breeding period. Those authors and others (Abayasekara and Wathes, 1999; Santos et al., 2008) have speculated that one of the mechanisms by which n-3 fatty acids improve fertility in dairy cows is likely by attenuating the pulsatile release of $\mathrm{PGF}_{2 \alpha}$ during late diestrus, thereby having

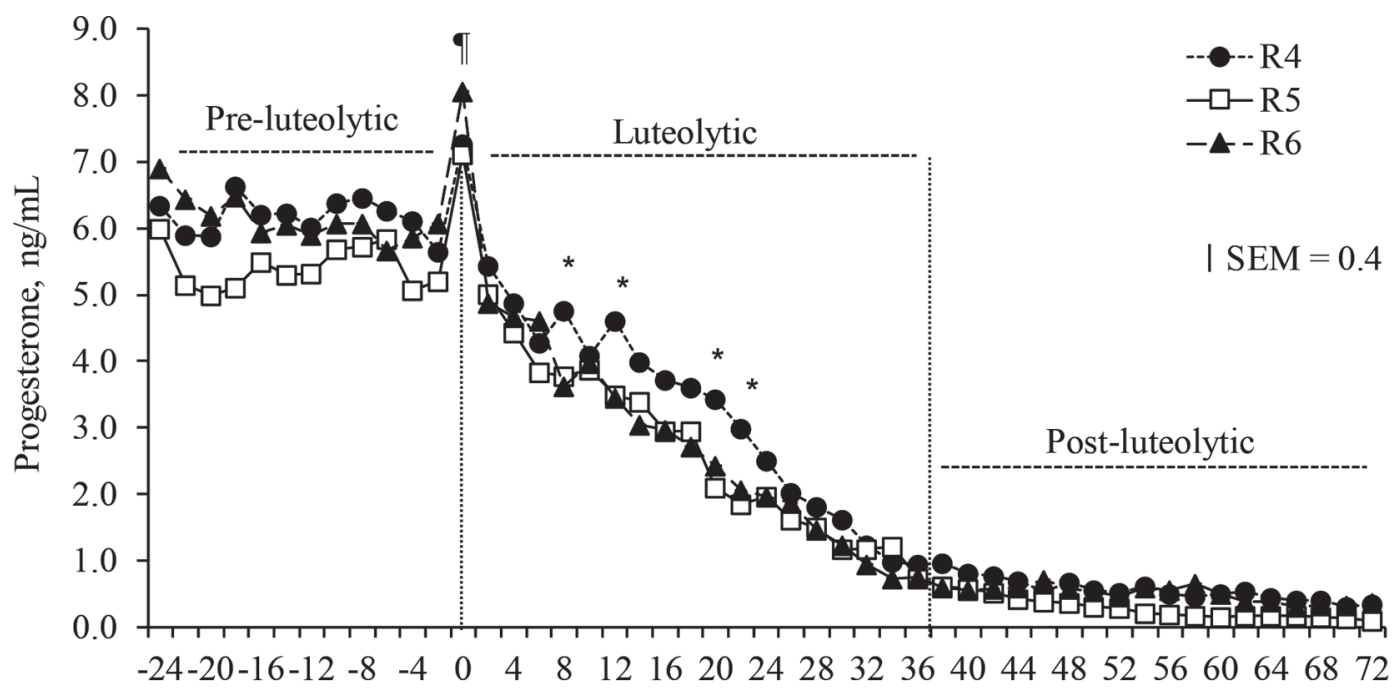

Hour relative to beginning of luteolysis

Figure 6. Concentrations of progesterone in plasma of lactating Holstein cows that underwent luteolysis and were fed a ratio of 3.9 to 1 (R4; $\mathrm{n}=11$ cows), 4.9 to $1(\mathrm{R} 5 ; \mathrm{n}=13)$, and 5.9 to $1(\mathrm{R} 6 ; \mathrm{n}=12) \mathrm{n}-6$ to $\mathrm{n}-3$ fatty acids in the diet during the preluteolytic, luteolytic, and postluteolytic periods. Within an hour, pairwise differences among treatments are represented as $* P<0.05, \boldsymbol{\Upsilon} P<0.10$. 
protective effects on CL maintenance. Although cows fed R4, which consumed more n-3 fatty acids, primarily EPA and DHA, had some attenuation of the largest pulse of $\mathrm{PGF}_{2 \alpha}$, they also had more total pulses because of an increase in number of pulses during the luteolytic period. Feeding n-3 fatty acids from fish (Mattos et al., 2002) or plant sources (Dirandeh et al., 2013) decreased the uterine synthesis of $\mathrm{PGF}_{2 \alpha}$ after a challenge with oxytocin, suggesting that these fatty acids have the ability to attenuate a large pulsatile release of PG. On the other hand, the increased number of pulses in cows fed R4 could be interpreted as favoring luteolysis (Schramm et al., 1983). In sheep, approximately 5 pulses of $\mathrm{PGF}_{2 \alpha}$ in a 25 -h period were required to induce complete luteolysis (Schramm et al., 1983). The number of PGFM pulses has been characterized in heifers, as they typically have $2.4,2.3$, and 2.2 pulses during the preluteolytic, luteolytic, and postluteolytic periods, respectively (Ginther et al., 2010). These values are similar to those observed for lactating dairy cows in the current experiment. The average number of pulses varied with diet but, in general, cows undergoing luteolysis had 2.0 preluteolytic PGFM pulses, 2.4 luteolytic PGFM pulses, and 1.1 postluteolytic PGFM pulses. On the other hand, PG are important mediators of conceptus development (Dorniak et al., 2011), and smaller more frequent pulses might indicate increased supply of PG needed to mediate the effects of IFN- $\tau$ on the endometrium during conceptus elongation (Dorniak et al., 2011). Indeed, genes related to supply of precursors and synthesis of prostaglandins increase substantially in the trophectoderm during the onset of conceptus elongation, and were highly correlated with the expression of PPARG (Ribeiro et al., 2016). Inter- estingly, endometrial expression of PPARG increased when cows were fed more n-3 fatty acids in the present experiment. Others have also shown that feeding fat supplements rich in n-3 fatty acids, flaxseed oil or fish oil, increased mRNA expression of PPARG in endometrial tissue in lactating dairy cows (Hutchinson et al., 2012). The negative linear association between mRNA expression of PPARG and the endometrial ratio of $\mathrm{n}-6$ to n-3 fatty acids observed herein suggests that incorporating more $\mathrm{n}-3$ fatty acids into the endometrium of dairy cows stimulates expression of $P P A R G$ that might have implications for conceptus development (Ribeiro et al., 2016) and pregnancy in cows supplemented with n-3 fatty acids (Silvestre et al., 2011; Sinedino et al., 2017).

For cows to undergo luteolysis, 3 pulses of $\mathrm{PGF}_{2 \alpha}$ were needed for progesterone to decline below $1.0 \mathrm{ng} /$ $\mathrm{mL}$. Only 1 lactating cow with only 2 pulses of $\mathrm{PGF}_{2 \alpha}$ had complete CL regression. Six of the 36 cows that underwent CL regression had progesterone concentrations between 0.4 and $0.7 \mathrm{ng} / \mathrm{mL}$ during the postluteolytic period compared with progesterone concentrations less than $0.3 \mathrm{ng} / \mathrm{mL}$ for the remaining 30 cows. The reasons for these relatively high concentrations of progesterone after luteolysis are either lack of complete CL regression, in which a portion of the luteal cells remain active, or simply late luteolysis, with not enough time for the death of the CL to result in concentrations of progesterone to drop below $0.3 \mathrm{ng} / \mathrm{mL}$ within the 23-d sampling period. Cows receiving different doses of $\mathrm{PGF}_{2 \alpha}$ on $\mathrm{d} 5$ of the estrous cycle had, in some cases, incomplete luteal regression (Nascimento et al., 2014). In a group of cows receiving $\mathrm{PGF}_{2 \alpha}$ between $\mathrm{d} 8$ to 13 of the estrous cycle, 1 cow had a decline followed by a

Table 4. Effect of altering the ratio of dietary n-6 to n-3 fatty acids on endometrium fatty acid profile of lactating Holstein cows on d 8 of the estrous cycle (LSM \pm SEM)

\begin{tabular}{|c|c|c|c|c|c|c|}
\hline Fatty acid, $\%$ of identified fatty acids & \multicolumn{3}{|c|}{ Treatment $^{1}$} & \multicolumn{3}{|c|}{$P$-value ${ }^{2}$} \\
\hline C16:0 & $27.70 \pm 0.80$ & $27.88 \pm 0.53$ & $27.20 \pm 0.46$ & 0.62 & 0.59 & 0.55 \\
\hline C18:0 & $27.60 \pm 1.61$ & $25.19 \pm 1.08$ & $24.84 \pm 0.93$ & 0.34 & 0.15 & 0.48 \\
\hline $\mathrm{C} 18: 1$ cis -9 & $12.18 \pm 1.37$ & $13.77 \pm 0.91$ & $12.55 \pm 0.79$ & 0.51 & 0.81 & 0.26 \\
\hline $\mathrm{C} 18: 2$ cis- 9, cis- 12 & $12.40 \pm 1.40$ & $13.50 \pm 0.93$ & $14.44 \pm 0.81$ & 0.43 & 0.22 & 0.95 \\
\hline $\mathrm{C} 20: 4$ cis-7,cis-10,cis-13,cis-16 & $9.05 \pm 0.94$ & $11.64 \pm 0.63$ & $13.41 \pm 0.54$ & $<0.01$ & $<0.01$ & 0.62 \\
\hline C20:5 cis-5,cis-8,cis-11,cis-14,cis-17 & $2.85 \pm 0.21$ & $2.14 \pm 0.14$ & $2.02 \pm 0.12$ & $<0.01$ & $<0.01$ & 0.12 \\
\hline C22:6 cis-4,cis-7,cis-10,cis-13,cis-16,cis-19 & $3.30 \pm 0.53$ & $1.57 \pm 0.35$ & $1.08 \pm 0.31$ & $<0.01$ & $<0.01$ & 0.20 \\
\hline Total n-6 & $23.55 \pm 2.05$ & $27.16 \pm 1.36$ & $29.89 \pm 1.18$ & 0.04 & 0.01 & 0.81 \\
\hline Total n-3 & $6.15 \pm 0.62$ & $3.72 \pm 0.41$ & $3.08 \pm 0.36$ & $<0.01$ & $<0.01$ & 0.12 \\
\hline $\mathrm{n}-6$ to $\mathrm{n}-3$ ratio & $4.53 \pm 1.12$ & $7.99 \pm 0.75$ & $9.85 \pm 0.65$ & $<0.01$ & $<0.01$ & 0.43 \\
\hline
\end{tabular}

${ }^{1} \mathrm{R} 4$ = ratio of 4 to 1 of n- 6 to n- 3 fatty acids; R $5=$ ratio of 5 to 1 of n- 6 to n- 3 fatty acids; $R 6$ = ratio of 6 to 1 of n- 6 to n- 3 fatty acids.

${ }^{2} \mathrm{TRT}=$ effect of treatment; Linear $=$ linear effect of altering the ratio of n- 6 to n-3 fatty acids; Quad $=$ quadratic effect of altering the ratio of n- 6 to n-3 fatty acids. 
口R4 QR5 QR6
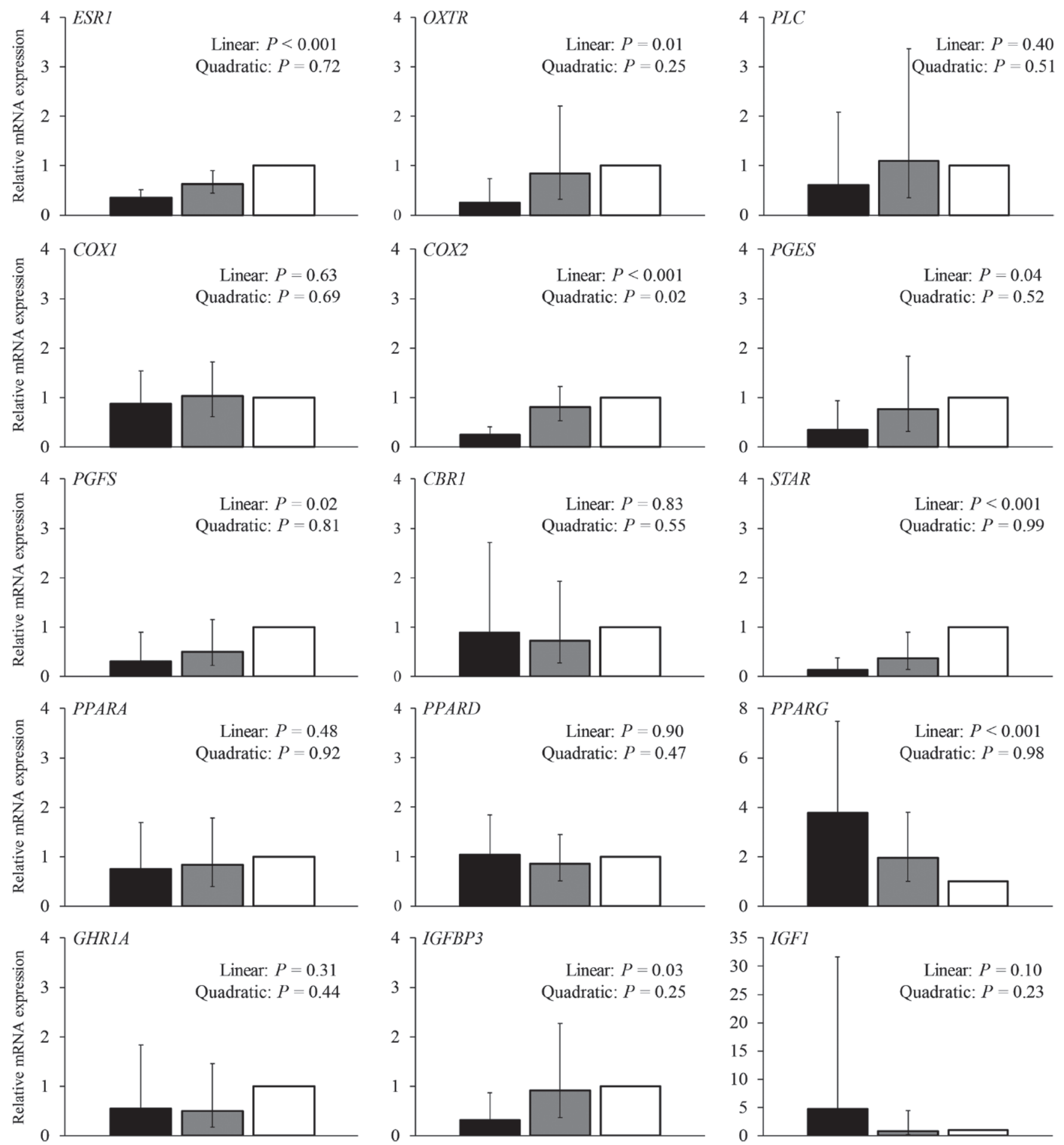

Figure 7. Expression of genes related to prostaglandin synthesis $(E S R 1=$ estrogen receptor $1 ; O X T R=$ oxytocin receptor; PLC $=$ phospholipase $\mathrm{C} ; C O X 1=$ cyclooxygenase $1 ; C O X 2=$ cyclooxygenase $2 ; P G F S=$ prostaglandin $\mathrm{F}$ synthase; PGES = prostaglandin E synthase; $C B R 1=$ prostaglandin $\mathrm{E}_{2}$ 9-ketoreductase $)$; cholesterol and fatty acid metabolism $(S T A R=$ steroidogenic acute regulatory protein; $P P A R A=$ peroxisome proliferator-activated receptor $\alpha ; P P A R D=$ peroxisome proliferator-activated receptor delta; and $P P A R G=$ peroxisome proliferator-activated receptor gamma); and somatotropic axis $(G H R 1 A=$ growth hormone receptor-1A; IGFBP3= insulin-like growth factor binding protein-3; and IGF1 = insulin-like growth factor-1) in the endometrium of lactating Holstein cows fed a ratio of 3.9 to 1 (R4), 4.9 to 1 (R5), and 5.9 to 1 (R6) n-6 to n-3 fatty acids. The linear and quadratic effects of altering the dietary ratio of n- 6 to n-3 fatty acids are depicted in each figure. Values represent the fold change relative to R6 and error bars represent the $95 \%$ CI. 

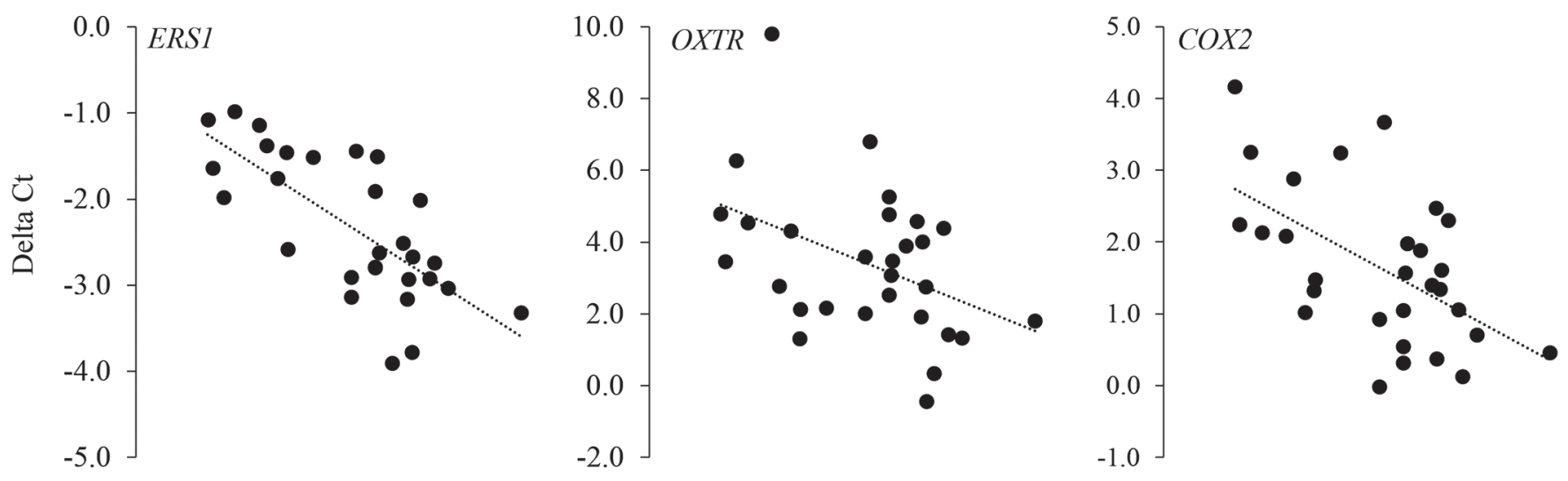

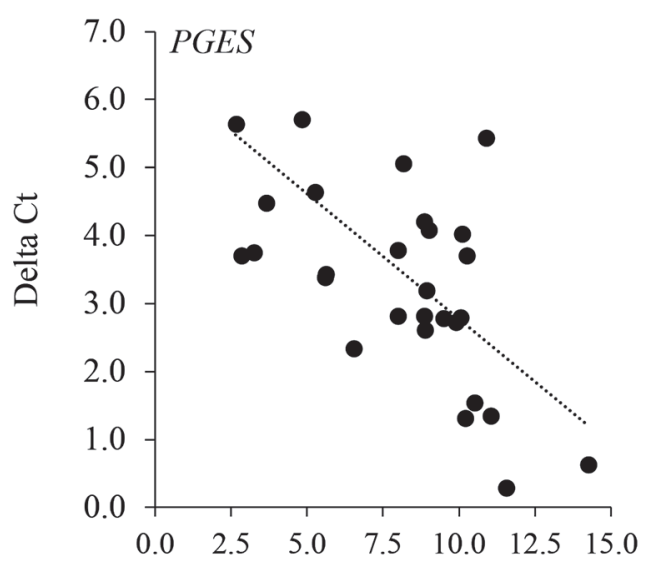

Endometrial n-6 to n-3 fatty acids

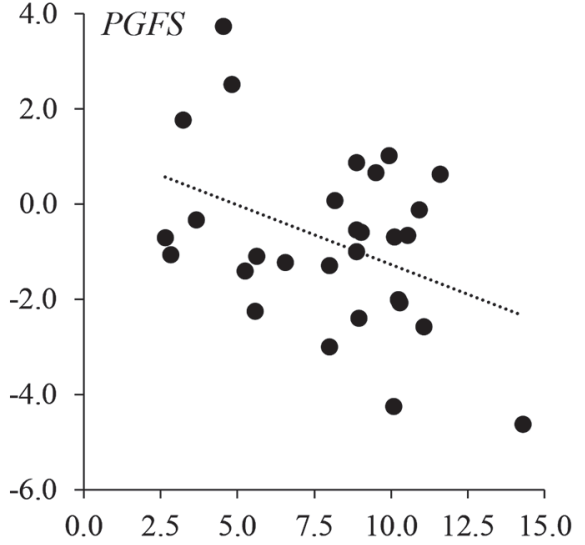

Endometrial n-6 to n-3 fatty acids

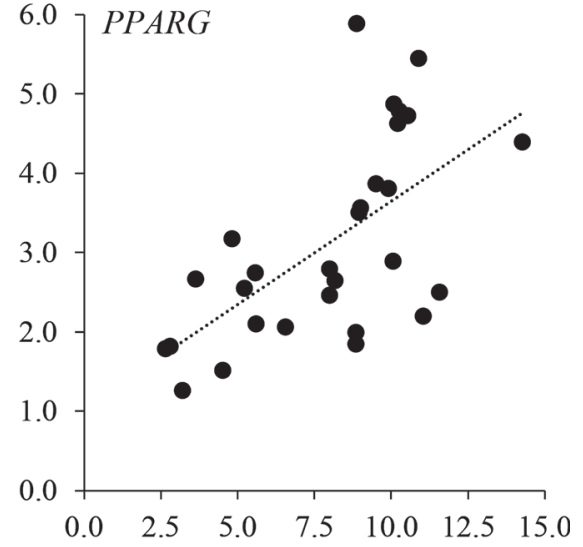

Endometrial n-6 to n-3 fatty acids

Figure 8. Regression analyses between expression of selected genes (delta cycle threshold; Ct) and the ratio of $n-6$ to $n-3$ fatty acids in the endometrium of dairy cows. Expression of ESR1 (estrogen receptor $1 ; \mathrm{R}^{2}=0.52$ ), OXTR (oxytocin receptor; $\mathrm{R}^{2}=0.18$ ), COX2 (cyclooxygenase $\left.2 ; \mathrm{R}^{2}=0.32\right), P G E S$ (prostaglandin E synthase; $\left.\mathrm{R}^{2}=0.35\right)$, and $P G F S$ (prostaglandin $\mathrm{F}$ synthase; $\left.\mathrm{R}^{2}=0.16\right)$ was positively associated $(P<$ 0.01 ) with the ratio of $\mathrm{n}-6$ to $\mathrm{n}-3$ fatty acids observed in the endometrium, whereas the expression of $P P A R G$ (peroxisome proliferator-activated receptor gamma; $\left.\mathrm{R}^{2}=0.38\right)$ was negative-associated $(P<0.001)$ with the ratio of $\mathrm{n}-6$ to $\mathrm{n}-3$ fatty acids in the endometrium of dairy cows.

rebound in progesterone concentrations (Chenault et al., 1976). To our knowledge, the same phenomenon has not been characterized in late diestrus with cows undergoing spontaneous luteolysis. Incomplete CL regression after a standard dose of $\mathrm{PGF}_{2 \alpha}$ treatment on $\mathrm{d} 5$ was expected because many of the luteal cells remain unresponsive to the cell death signaling induced by $\mathrm{PGF}_{2 \alpha}$ typically observed in a more mature CL.

Substantial variability exists in the frequency and amplitude of $\mathrm{PGF}_{2 \alpha}$ pulses that induce spontaneous luteolysis in heifers, but typically 4 to 8 discrete pulses occur at intervals of 6 to $12 \mathrm{~h}$ (Kindahl et al., 1976; Silvia et al., 1991). Thatcher et al. (1986) studied 10 Friesian heifers in which 5 received saline and 5 received 3 mg of $17 \beta$-estradiol on d 13 of the estrous cycle. Those authors identified 39 pulses of PGFM in the 10 heifers (3.9/heifer), of which 21 occurred preluteolysis. Kindahl et al. (1976) characterized 4 distinct $\mathrm{PGF}_{2 \alpha}$ pulses that occurred within a period of approximately $30 \mathrm{~h}$ for luteolysis to occur in heifers. Although 1 lactating cow with only 2 pulses of $\mathrm{PGF}_{2 \alpha}$ had complete CL regression, results from the current experiment suggest that $3 \mathrm{PGF}_{2 \alpha}$ pulses are required based on the measures of reliability of using $\mathrm{PGF}_{2 \alpha}$ pulses as a predictor of luteolysis. Infusion of low doses of $\mathrm{PGF}_{2 \alpha}$ to mimic the pulses observed during luteolysis depicts a similar pattern of PGFM pulses and subsequent CL regression in heifers as those observed during spontaneous luteolysis (Ginther et al., 2009).

Similar to findings observed by Ginther et al. (2007) in heifers, cows showed an initial increase in circulating concentrations of progesterone before a sharp decrease during the preluteolytic period. The individual profile of a heifer that underwent spontaneous luteolysis clearly showed the pulsatile pattern of progesterone concentrations during late diestrus with an increase in concentration preceding a sharp decline during luteolysis (Thatcher et al., 1986). Ginther et al. (2007) 
observed that progesterone concentrations and blood flow to the CL increased and then decreased during the process of spontaneous luteolysis. A similar phenomenon was characterized in heifers induced to have luteolysis with infusion of low doses of $\mathrm{PGF}_{2 \alpha}$ to mimic the pulses observed during spontaneous luteolysis (Ginther et al., 2009).

When exogenous $\mathrm{PGF}_{2 \alpha}$ was administered to lactating cows in the present experiment, functional luteolysis occurred within $24 \mathrm{~h}$ and progesterone concentrations dropped below $1.0 \mathrm{ng} / \mathrm{mL}$. Burke et al. (1997) found that feeding a diet enriched with n-3 fatty acids from fish meal increased the proportion of cows with progesterone concentrations in plasma above $1.0 \mathrm{ng} / \mathrm{mL}$ at $48 \mathrm{~h}$ after a $\mathrm{PGF}_{2 \alpha}$ injection, suggesting a protective effect of the n-3 fatty acids on the CL. Based on experi- ments in vitro and work with exogenous administration of oxytocin and estradiol to induce pulses of $\mathrm{PGF}_{2 \alpha}$ (Mattos et al., 2000, 2003), one could expect that a diet enriched with n-6 fatty acids would favor luteolysis and a diet enriched with n-3 fatty acids would possess antiluteolytic properties. However, results from the present experiment, in which the dietary ratio of n-6 to n-3 fatty acids was altered, suggest that the changes implemented, within the ranges of n-3 fatty acids consumed by these cows, were not sufficient to exert any protective effects on the CL against an exogenous $\mathrm{PGF}_{2 \alpha}$ injection. Cows fed $\mathrm{R} 4$ consumed a diet containing $0.327 \%$ n-3 fatty acids, mostly EPA and DHA, which are potent regulators of cell metabolism (Calder, 2012). Nevertheless, this concentration of n-3 fatty acids is usually less than those of diets typically

Low aMod aHigh
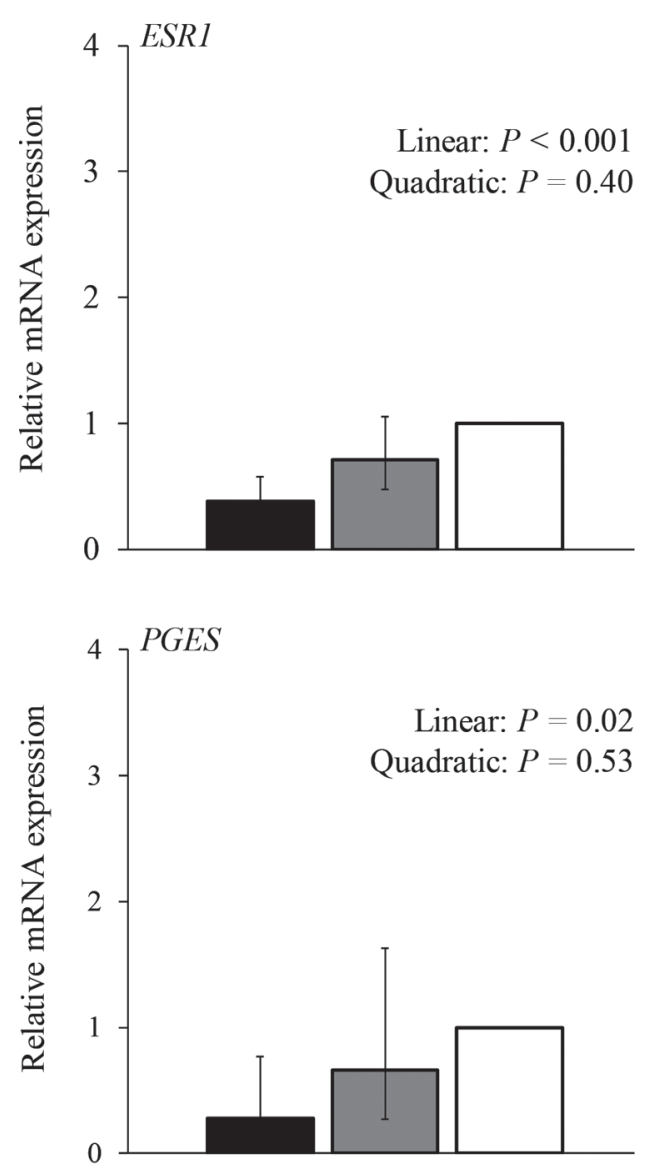
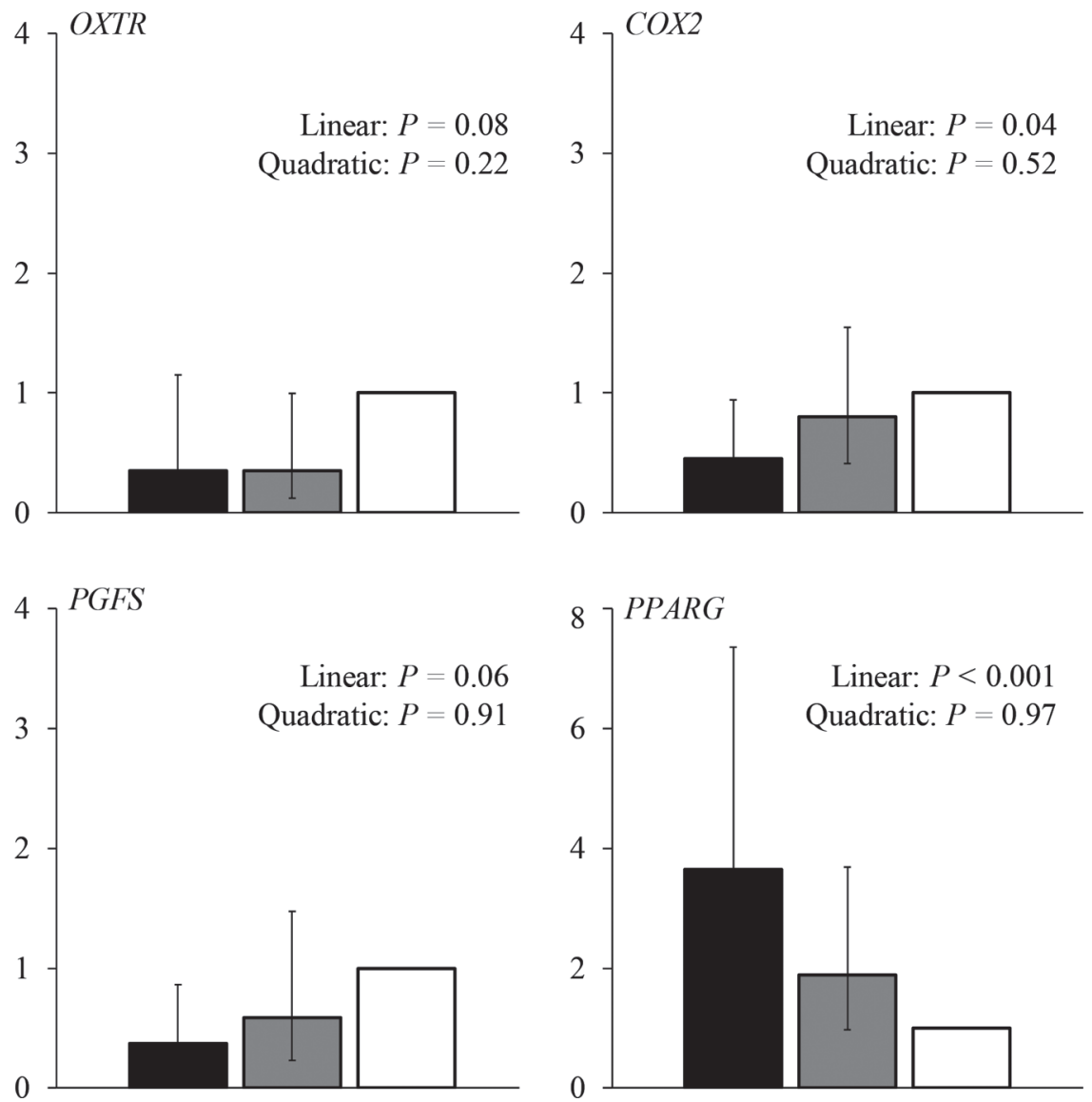

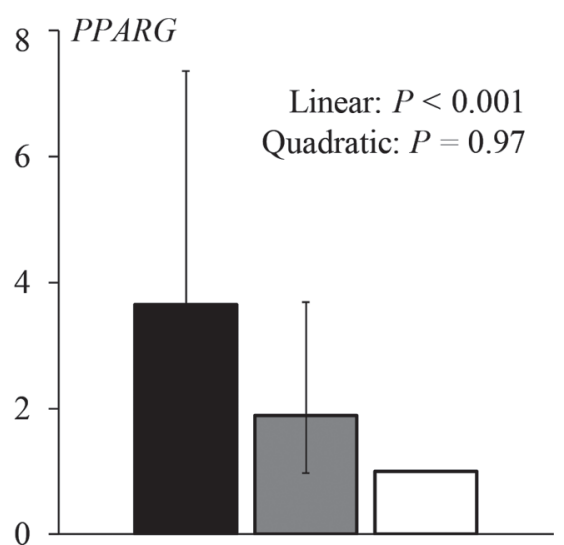

Figure 9. Expression of selected genes according to the concentration of n-6 to n-3 fatty acids in the endometrium of dairy cows. Endometrium was categorized according to the ratio of n- 6 to n-3 fatty acids observed by MS as low ratio (mean $=4.45$, range $=2.65$ to 5.6 ), moderate ratio $($ mean $=8.81$, range $=8.12$ to 9.91$)$, or high ratio (mean $=11.10$, range $=10.06$ to 14.27$)$. Genes differentially expressed included ESR1 (estrogen receptor 1), OXTR (oxytocin receptor), COX2 (cyclooxygenase 2), PGES (prostaglandin E synthase), PGFS (prostaglandin F synthase), and PPARG (peroxisome proliferator-activated receptor gamma). The linear and quadratic effects of ratio of n- 6 to n-3 fatty acids analyzed in the endometrium by MS are depicted in each figure. Values represent the fold change relative to high ratio of n-6 to n-3 fatty acids and error bars represent the $95 \%$ CI. 
consumed when cows graze pasture forages (Glasser et al., 2013). Cows grazing subtropical or temperate forages as the sole dietary ingredient consume diets with 1.1 to $2.2 \%$ total fatty acids, of which n- 3 fatty acids, particularly $\alpha$-linolenic acid, represent 30 to $60 \%$ of those fatty acids (Glasser et al., 2013). In those production systems, it would not be unusual for cows grazing pasture forages and supplemented with concentrates to consume diets with a 1 to 1 ratio of n- 6 to n- 3 fatty acids and ingest 100 to $200 \mathrm{~g} / \mathrm{d}$ of $\alpha$-linolenic acid, whereas cows in R4 ingested $20.3 \mathrm{~g} / \mathrm{d}$ of EPA plus DHA and $76.3 \mathrm{~g} / \mathrm{d}$ of total n-3 fatty acids (Greco et al., 2015). A 1 to 1 ratio of n- 6 to n- 3 fatty acids is difficult to achieve in TMR-based diets when the main forage is corn silage, which typically contains primarily n- 6 fatty acids. It is possible that luteolytic responses to n-3 fatty acids might be dose-dependent in dairy cows, and larger quantities consumed might further increase the availability of those fatty acids in reproductive tissues (Zachut et al., 2010), thereby suppressing the pulsatile release of $\mathrm{PGF}_{2 \alpha}$ and delaying luteolysis, although that remains to be demonstrated in vivo.

The pulse of PGFM observed with a luteolytic dose of $25 \mathrm{mg}$ of $\mathrm{PGF}_{2 \alpha}$ was massive in both nonlactating cows evaluated, reaching concentrations that were 10 to 15 fold those observed in the typical spontaneous PGFM pulse during the luteolytic period for lactating cows fed altered n- 6 to n-3 ratios. Likewise, the duration of the concentration of PGFM above the thresholds observed for the peak of PGFM pulse in cows undergoing spontaneous luteolysis was long, lasting several hours (e.g., $8 \mathrm{~h}$ ), either because the release and absorption of dinoprost from the site of injection was slow or because the half-life of PGFM is longer than the short half-life typically described for $\mathrm{PGF}_{2 \alpha}$. In pigs, after intravenous bolus injection of PGFM, the elimination half-life averaged $( \pm \mathrm{SD}) 15.0 \pm 1.3$ min (Martin and Liptrap, 1981), whereas in heifers, the elimination half-life of PGFM averaged 18 min following intrauterine administration of $200 \mu \mathrm{g}$ of $\mathrm{PGF}_{2 \alpha}$ (Williams et al., 1983). These values are 1.7 to 2 fold longer than the elimination half-life of $9.0 \pm 0.9 \mathrm{~min}$ for $\mathrm{PGF}_{2 \alpha}$ in heifers (Shrestha et al., 2012), which explains the long duration of high concentrations of PGFM after the injection of $25 \mathrm{mg}$ of dinoprost.

Altering the dietary ratio of $n-6$ to $n-3$ fatty acids did not affect the concentrations of progesterone in plasma of dairy cows. All treatments were designed to have the same concentrations of fatty acids, and differences in PUFA concentrations among diets were small. Therefore, differences in progesterone concentrations typically observed with addition of dietary fat (Staples et al., 1998; Santos et al., 2008) or changes in progesterone clearance (Hawkins et al., 1995) were not anticipated. In fact, the clearance of progesterone after induced luteolysis did not change among treatments. Interestingly, progesterone concentrations of lactating dairy cows during late diestrus displayed a pulsatile fashion. Ginther et al. (2011) showed a concurrent and coordinated pulse of $\mathrm{LH}$ that preceded the pulses of progesterone during the preluteolytic period in dairy heifers. Although LH was not quantified in plasma samples in our experiment, it is reasonable to suggest that a similar phenomenon also occurs in lactating dairy cows (Procknor et al., 1986). In mid diestrus, cows have LH pulses of high amplitude, varying by 1.2 to $7.0 \mathrm{ng} / \mathrm{mL}$, and of low frequency, averaging 6 to 8 pulses per day, which was described as not having an inherent rhythmic pattern (Rahe et al., 1980).

The fatty acid profile of the endometrial tissue resembled that of the dietary fatty acids offered to cows. Others have also shown that the fatty acid profile of endometrial phospholipids is directly influenced by the fatty acids consumed in the diet (Bilby et al., 2006). In fact, altering the dietary profile of fatty acids influences numerous reproductive tissues, including the profiles of fatty acids in follicular fluid, granulosa cells, and the cumulus oocyte complex (Zachut et al., 2010), which can influence not only endometrial but also ovarian function that interplays with the uterus to induce luteolytic pulses of $\mathrm{PGF}_{2 \alpha}$. Increasing the ratio of $n-6$ to n-3 fatty acids, with concurrent increased intake of linoleic acid, resulted in a greater proportion of arachidonic acid in the endometrium. Arachidonic acid is the most biologically active n-6 fatty acid and can be synthetized by elongation and desaturation of linoleic acid (Abayasekara and Wathes, 1999; Leonard et al., 2004). Likewise, increasing the intake of EPA, by decreasing the ratio of n- 6 to $n-3$ fatty acids in the diet granted greater proportion of EPA in the endometrium. Concentrations of EPA and DHA were greater in the caruncular tissue when cows were supplemented with $200 \mathrm{~g} / \mathrm{d}$ of fish oil, starting at $21 \mathrm{~d}$ prepartum, compared with cows supplemented with olive oil (Mattos et al., 2004). Furthermore, cows supplemented with fish oil had increased concentrations of EPA and DHA in the endometrium on $\mathrm{d} 17$ of the estrous cycle (Bilby et al., 2006; Childs et al., 2008). Therefore, results from the current experiment corroborate data in the literature suggesting that manipulation of the dietary fatty acids profile affects the fatty acids composition of the reproductive tissues. Furthermore, these changes in the fatty acid profile of the endometrium might lead to changes in gene expression. In late diestrus, progesterone downregulates its own receptors in the superficial epithelium, leading to a loss in ability to inhibit the expression of estrogen and oxytocin receptors in the endometrium (Silvia et al., 1991). Upregulation of en- 
dometrial estrogen and oxytocin receptors and binding to respective ligands initiates the luteolytic cascade by activating endometrial phospholipases to release arachidonic acid from the membrane phospholipids (Mattos et al., 2000). As a result, arachidonic acid is available for the synthesis of $\mathrm{PGF}_{2 \alpha}$ and other $\mathrm{PG}$ (Mattos et al., 2000). In the current experiment, cows fed more n- 6 relative to n-3 fatty acids had greater expression of estradiol and oxytocin receptors and enzymes involved in PG synthesis, which could be interpreted as favoring the luteolytic process. Feeding more R6 enriched the endometrium with increased concentration of linoleic and arachidonic acids, the substrate for PG synthesis. Waters et al. (2012) demonstrated that the estrogen receptor was downregulated on d 17 of the estrous cycle in the endometrium of cows with high n-3 fatty acid content compared with controls, which was also observed in cows fed R4 in the present experiment. Therefore, it is possible that changes in the pulsatile pattern of PGFM observed in the current experiment under spontaneous luteolysis, and that of cows induced to have $\mathrm{PGF}_{2 \alpha}$ pulses after treatment with estradiol and oxytocin, were influenced not only by the availability of fatty acid precursors for PG, but also by changes in the gene signaling that favor PG synthesis (i.e., R6 $>\mathrm{R} 4$ ). Likewise, steroidogenic acute regulatory protein is a rate-limiting enzyme responsible for the transport of cholesterol within the mitochondria for steroid synthesis (Manna et al., 2009). Several transcription factors are involved in the regulation of STAR (Manna et al., 2009), and arachidonic acid is involved in one of the signaling pathways that upregulates the expression and protein translation of the STAR enzyme (Stocco et al., 2005). Consistent with these findings, cows in the current experiment fed R6 had greater concentrations of arachidonic acid in the endometrium and increased abundance of STAR mRNA. Furthermore, positive relationships were observed between mRNA expressions of ESR1, OXTR, COX2, PGES, and PGFS with increased ratio of n- 6 to n- 3 fatty acids present in the endometrium.

\section{CONCLUSIONS}

Altering the ratio of n- 6 to n-3 fatty acids in the diet of lactating dairy cows influenced the pattern of prostaglandin synthesis. Increasing the ratio of n-6 to n-3 fatty acids increased the amplitude but decreased the frequency of PGFM pulses. Furthermore, increasing the ratio of n- 6 to n- 3 fatty acids from $\mathrm{R} 4$ to $\mathrm{R} 6$ resulted in endometrial responses that included an increase in concentration of arachidonic acid and a decrease in concentration of EPA and DHA, increases in mRNA expressions of estrogen and oxytocin receptors, cyclooxygenase 2, PGE and PGF synthase, steroidogenic acute regulatory protein, and insulin-like growth factor binding protein-3, but decreased the expression of peroxisome proliferator activated receptor gamma and insulin-like growth factor 1 . These changes in endometrial gene expression were associated with changes in endometrial content of fatty acids. In spite of these dynamic changes caused by dietary fatty acids manipulations, length of the estrous cycle was not altered. Three pulses of PGFM was the best predictor that resulted in the highest combined sensitivity and specificity for luteolysis in lactating dairy cows.

\section{ACKNOWLEDGMENTS}

The authors thank the staff of the University of Florida Dairy Unit (Gainesville) for assistance with managing the cows during the experiment. Thanks to Timothy Garrett from University of Florida for assistance with fatty acid analysis; Oliver Ginther and Mohd Amin Beg from the University of Wisconsin (Madison) for assistance with the PGFM assay and the donation of the PGFM conjugate; Sergei Senikov (University of Florida) for assistance with laboratory analyses; Kevin Murphy (Virtus Nutrition LLC, Corcoran, CA) for discussions during the design of the experiment. Partial financial support for this experiment was provided by Virtus Nutrition LLC.

\section{REFERENCES}

Abayasekara, D. R. E., and D. C. Wathes. 1999. Effects of altering dietary fatty acid composition on prostaglandin synthesis and fertility. Prostaglandins Leukot. Essent. Fatty Acids 61:275-287.

Bilby, T. R., T. Jenkins, C. R. Staples, and W. W. Thatcher. 2006. Pregnancy, bovine somatotropin, and dietary n-3 fatty acids in lactating dairy cows: III. Fatty acid distribution. J. Dairy Sci. 89:3386-3399.

Bligh, E. G., and W. J. Dyer. 1959. A rapid method of total lipid extraction and purification. Can. J. Biochem. Physiol. 37:911-917.

Boshier, D. P., R. J. Fairclough, and H. Holloway. 1987. Assessment of sheep blastocyst effects on neutral lipids in the uterine caruncular epithelium. J. Reprod. Fertil. 79:569-573.

Brinsfield, T. H., and H. W. Hawk. 1973. Control by progesterone of the concentration of lipid droplets in epithelial cells of the sheep endometrium. J. Anim. Sci. 36:919-922.

Burke, J. M., C. R. Staples, C. A. Risco, R. L. De La Sota, and W. W. Thatcher. 1997. Effect of ruminant grade menhaden fish meal on reproductive and productive performance of lactating dairy cows. J. Dairy Sci. 80:3386-3398.

Caldari-Torres, C., C. Rodriguez-Sallaberry, E. S. Greene, and L. Badinga. 2006. Differential effects of n-3 and n-6 fatty acids on prostaglandin $\mathrm{F}_{2 \alpha}$ production by bovine endometrial cells. J. Dairy Sci. 89:971-977.

Calder, P. C. 2012. Long-chain fatty acids and inflammation. Proc. Nutr. Soc. 71:284-289.

Chenault, J. R., W. W. Thatcher, P. S. Kalra, R. M. Abrams, and C. J. Wilcox. 1976. Plasma progestins, estradiol, and luteinizing 
hormone following prostaglandin F2 alpha injection. J. Dairy Sci. 59:1342-1346.

Childs, S., A. A. Hennessy, J. m. Sreenan, D. C. Wathes, Z. Cheng, C. Stanton, M. G. Diskin, and D. A. Kenny. 2008. Effect of level of dietary n-3 polyunsaturated fatty acid supplementation on systemic and tissue fatty acid concentrations and on selected reproductive variables in cattle. Theriogenology 70:595-611.

Damgaard, B. M., M. R. Weisbierg, and T. Larsen. 2013. Priming the cow for lactation by rapeseed supplementation in the dry period. J. Dairy Sci. 96:3652-3661.

Dirandeh, E., A. Towhidi, Z. Ansari Pirsaraei, F. Adib Hashemi, M. Ganjkhanlou, S. Zeinoaldini, A. Rezaei Roodbari, T. Saberifar, and H. V. Petit. 2013. Plasma concentrations of PGFM and uterine and ovarian responses in early lactation dairy cows fed omega-3 and omega-6 fatty acids. Theriogenology 80:131-137.

Dorniak, P., F. W. Bazer, and T. E. Spencer. 2011. Prostaglandins regulate conceptus elongation and mediate effects of interferon tau on the ovine uterine endometrium. Biol. Reprod. 84:1119-1127.

Ginther, O. J., R. R. Araujo, M. P. Palhão, B. L. Rodrigues, and M. A. Beg. 2009. Necessity of sequential pulses of prostaglandin F2alpha for complete physiologic luteolysis in cattle. Biol. Reprod. 80:641-648.

Ginther, O. J., M. J. Fuenzalida, H. K. Shrestha, and M. A. Beg. 2011. Concomitance of luteinizing hormone and progesterone oscillations during the transition from preluteolysis to luteolysis in cattle. Domest. Anim. Endocrinol. 40:77-86.

Ginther, O. J., H. K. Shrestha, M. J. Fuenzalida, A. K. M. Shahiduzzaman, and M. A. Beg. 2010. Characteristics of pulses of 13,14-dihydro-15-keto-prostaglandin F2alpha before, during, and after spontaneous luteolysis and temporal intrapulse relationships with progesterone concentrations in cattle. Biol. Reprod. 82:1049-1056.

Ginther, O. J., L. A. Silva, R. R. Araujo, and M. A. Beg. 2007. Temporal associations among pulses of 13,14-Dihydro-15-keto-PGF ${ }_{2 a l p h a}$, luteal blood flow, and luteolysis in cattle. Biol. Reprod. 76:506-513.

Glasser, F., M. Doreau, G. Maxin, and R. Baumont. 2013. Fat and fatty acid content and composition of forages: A meta-analysis. Anim. Feed Sci. Technol. 185:19-34.

Greco, L. F., J. T. Neves Neto, A. Pedrico, R. A. Ferrazza, F. S. Lima, R. S. Bisinotto, N. Martinez, M. Garcia, E. S. Ribeiro, G .C. Gomes, J. H. Shin, M. A. Ballou, W. W. Thatcher, C. R. Staples, and J. E. P. Santos. 2015. Effects of altering the ratio of dietary n-6 to n-3 fatty acids on performance and inflammatory responses to a lipopolysaccharide challenge in lactating Holstein cows. J. Dairy Sci. 98:602-617.

Gulliver, C. E., M. A. Friend, B. J. King, and E. H. Clayton. 2012. The role of omega-3 polyunsaturated fatty acids in reproduction of sheep and cattle. Anim. Reprod. Sci. 131:9-22.

Hawkins, D. E., K. D. Niswender, G. M. Oss, C. L. Moeller, K. G. Odde, H. R. Sawyer, and G. D. Niswender. 1995. An increase in serum lipids increases luteal lipid content and alters the disappearance rate of progesterone in cows. J. Anim. Sci. 73:541-545.

Hutchinson, I. A., A. A. Hennessy, S. M. Waters, R. J. Dewhurst, A. C. O. Evans, P. Lonergan, and S. T. Butler. 2012. Effect of supplementation with different fat sources on the mechanisms involved in reproductive performance in lactating dairy cattle. Theriogenology $78: 12-27$.

Kindahl, H., L. E. Edqvist, E. Granstrom, and A. Bane. 1976. Release of prostaglandin-F2alpha as reflected by 15-Keto-13,14-Dihydroprostaglandin F2alpha in peripheral-circulation during normal luteolysis in heifers. Prostaglandins 11:871-878.

Leonard, A. E., S. L. Pereira, H. Sprecher, and Y. S. Huang. 2004 Elongation of long chain fatty acids. Prog. Lipid Res. 43:36-54.

Livak, K. J., and T. D. Schmittgen. 2001. Analysis of relative gene expression data using real-time quantitative PCR and the $2^{-\Delta \Delta C T}$ method. Methods 25:402-408.

Mann, G. E., and G. E. Lamming. 2006. Timing of prostaglandin $F_{2 \alpha}$ release episodes and oxytocin receptor development during luteolysis in the cow. Anim. Reprod. Sci. 93:328-336.

Manna, P. R., M. T. Dyson, and D. M. Stocco. 2009. Regulation of the steroidogenic acute regulatory protein gene expression: present and future perspectives. Mol. Hum. Reprod. 15:321-333.
Martin, K. A., and R. M. Liptrap. 1981. Half-life of 13,14-dihydro15-keto prostaglandin $\mathrm{f} 2$ alpha in peripheral plasma of the pig. Res. Vet. Sci. 31:387-389.

Mattos, R., A. Guzeloglu, L. Badinga, C. R. Staples, and W. W. Thatcher. 2003. Polyunsaturated fatty acids and bovine interferonт modify phorbol ester-induced secretion of prostaglandin $\mathrm{F}_{2 \alpha}$ and expression of prostaglandin endoperoxide synthase- 2 and phospholipase- $\mathrm{A}_{2}$ in bovine endometrial cells. Biol. Reprod. 69:780-787.

Mattos, R., C. R. Staples, A. Arteche, M. C. Wiltbank, F. J. Diaz, T. C. Jenkins, and W. W. Thatcher. 2004. The effects of feeding fish oil on uterine secretion of $\mathrm{PGF}_{2 \alpha}$, milk composition, and metabolic status of periparturient Holstein cows. J. Dairy Sci. 87:921-932.

Mattos, R., C. R. Staples, and W. W. Thatcher. 2000. Effects of dietary fatty acids on reproduction in ruminants. Rev. Reprod. $5: 38-45$.

Mattos, R., C. R. Staples, J. Williams, A. Amorocho, M. A. McGuire, and W. W. Thatcher. 2002. Uterine, ovarian and production responses of lactating dairy cows to increasing dietary concentrations of menhaden fish meal. J. Dairy Sci. 85:755-764

McCracken, J. A., J. C. Carlson, M. E. Glew, J. R. Goding, D. T. Baird, K. Greem, and B. Samuelsson. 1972. Prostaglandin $\mathrm{F}_{2 \alpha}$ identified as a luteolytic hormone in sheep. Nat. New Biol. 238:129-134.

Nascimento, A. B., A. H. Souza, A. Keskin, R. Sartori, and M. C. Wiltbank. 2014. Lack of complete regression of the Day 5 corpus luteum after one or two doses of PGF $2 \alpha$ in nonlactating Holstein cows. Theriogenology 81:389-395.

NRC. 2001. Nutrient Requirements of Dairy Cattle. 7th rev. ed. Natl. Acad. Sci., Washington, DC.

Nuernberg, K., D. Dannenberger, K. Ender, and G. Nuernberg. 2007. Comparison of different methylation methods for the analysis of conjugated linoleic acid isomers by silver ion HPLC in beef lipids. J. Agric. Food Chem. 55:598-602.

Olsen, S. F., J. D. Sorensen, N. J. Secher, M. Hedegaard, T. B. Henriksen, H. S. Hansen, and A. Grant. 1992. Randomized controlled trial of effect of fish-oil supplementation on pregnancy duration. Lancet 339:1003-1007.

Petit, H. V., C. Germiquet, and D. Lebel. 2004. Effect of feeding whole, unprocessed sunflower seeds and flaxseed on milk production, milk composition, and prostaglandin secretion in dairy cows. J. Dairy Sci. 87:3889-3898.

Procknor, M., S. Dachir, R. E. Owens, D. E. Little, and P. G. Harms, 1986. Temporal relationship of the pulsatile fluctuation of luteinizing hormone and progesterone in cattle: A time series cross-correlation analysis. J. Anim. Sci. 62:191-198.

Pruessner, J. C., C. Kirschbaum, G. Meinlschmid, and D. H. Hellhammer. 2003. Two formulas for computation of the area under the curve represent measures of total hormone concentration versus time-dependent change. Psychoneuroendocrinology 28:916-931.

Rahe, C. H., R. E. Owens, J. L. Fleeger, H. J. Newton, and P. G. Harms. 1980. Pattern of plasma luteinizing hormone in the cyclic cow: dependence upon the period of the cycle. Endocrinology 107:498-503.

Ribeiro, E. S., J. E. P. Santos, and W. W. Thatcher. 2016. The role of lipids on the elongation of the preimplantation conceptus in ruminants. Reproduction 152:R115-R126.

Santos, J. E. P., T. R. Bilby, W. W. Thatcher, C. R. Staples, and F. T. Silvestre. 2008. Long chain fatty acids of diet as factors influencing reproduction in cattle. Reprod. Domest. Anim. 43:23-30.

Schramm, W., L. Boyaird, M. E. Glew, G. Schramm, and J. A. McCracken. 1983. Corpus luteum regression induced by ultra-low pulses of prostaglandin $\mathrm{F}_{2 \alpha}$. Prostaglandins 26:347-364.

Sears, P. M., M. J. Paape, R. E. Pearson, and F. C. Gwazdauskas. 1978. Comparison between tail vein and jugular vein cannulation in cattle. J. Dairy Sci. 61:974-979.

Shrestha, H. K., M. A. Beg, R. R. Burnette, and O. J. Ginther. 2012. Plasma clearance and half-life of prostaglandin F2alpha: a comparison between mares and heifers. Biol. Reprod. 87:18.

Silvestre, F. T., T. S. M. Carvalho, N. Francisco, J. E. P. Santos, C. R. Staples, T. C. Jenkins, and W. W. Thatcher. 2011. Effects of differential supplementation of fatty acids during the peripartum 
and breeding periods of Holstein cows: I. Uterine and metabolic responses, reproduction, and lactation. J. Dairy Sci. 94:189-204.

Silvia, W. J., G. S. Lewis, J. A. McCracken, W. W. Thatcher, and L. Wilson Jr.. 1991. Hormonal regulation of uterine secretion of prostaglandin $\mathrm{F}_{2 \alpha}$ during luteolysis in ruminants. Biol. Reprod. 45:655-663.

Sinedino, L. D. P., P. M. Ronda, L. R. L. Souza, A. L. Lock, M. P. Boland, C. R. Staples, W. W. Thatcher, and J. E. P. Santos. 2017. Effects of supplementation with docosahexaenoic acid on reproduction of dairy cows. Reproduction 153:707-723.

Staples, C. R., J. M. Burke, and W. W. Thatcher. 1998. Influence of supplemental fats on reproductive tissue and performance of lactating dairy cows. J. Dairy Sci. 81:856-871.

Stocco, D. M., X. Wang, Y. Jo, and P. R. Manna. 2005. Multiple signaling pathways regulating steroidogenesis and steroidogenic acute regulatory protein expression: more complicated than we thought. Mol. Endocrinol. 19:2647-2659.

Thatcher, W. W., M. Terqui, J. Thimonier, and J. Mauleon. 1986. Effect of estradiol-17 beta on peripheral plasma concentration of 15-keto-13,14-dihydro PGF2 alpha and luteolysis in cyclic cattle. Prostaglandins 31:745-756.
Waters, S. M., G. S. Coyne, D. A. Kenny, D. E. MacHugh, and D. G. Morris. 2012. Dietary n-3 polyunsaturated fatty acid supplementation alters the expression of genes involved in the control of fertility in the bovine uterine endometrium. Physiol. Genomics 44:878-888.

Whitlock, L. A., D. J. Schingoethe, A. R. Hippen, K. F. Kalscheur, R. J. Baer, N. Ramaswamy, and K. M. Kasperson. 2002. Fish oil and extruded soybeans fed in combination increase conjugated linoleic acids in milk of dairy cows more than when fed separately. J. Dairy Sci. 85:234-243.

Williams, W. F., G. S. Lewis, W. W. Thatcher, and C. S. Underwood. 1983. Plasma 13,14-dihydro-15-keto-PGF alpha (PGFM) in pregnant and nonpregnant heifers prior to and during surgery and following intrauterine injection of PGF2 alpha. Prostaglandins 25:891-899.

Yuan, J. S., A. Reed, F. Chen, and C. N. Stewart. 2006. Statistical analysis of real-time PCR data. BMC Bioinformatics 7:85.

Zachut, M., A. Arieli, H. Lehrer, L. Livshitz, S. Yakoby, and U. Moallem. 2010. Effects of increased supplementation of n-3 fatty acids to transition dairy cows on performance and fatty acid profile in plasma, adipose tissue, and milk fat. J. Dairy Sci. 93:5877-5889. 